\title{
Field and petrological study of metasomatism and high-pressure carbonation from lawsonite eclogite-facies terrains, Alpine Corsica
}

\author{
Francesca Piccoli ${ }^{\mathrm{a}, *}$, Alberto Vitale Brovarone ${ }^{\mathrm{a}, *}$, Jay J. Ague ${ }^{\mathrm{b}, \mathrm{c}}$ \\ a Sorbonne Université, Muséum National d'Histoire Naturelle, UMR CNRS 7590, IRD, Institut de Minéralogie, de Physique des Matériaux et de Cosmochimie, IMPMC, 75005 Paris, France \\ b Department of Geology and Geophysics, Yale University, P.O. Box 208109, New Haven, CT 06520-8109, USA \\ c Peabody Museum of Natural History, Yale University, 170 Whitney Avenue, P.O. Box 208118, New Haven, CT, 06520-8118, USA
}

Keywords:

subduction

HP carbonation

reactive fluid flow

metasomatism

carbon cycle

Alpine Corsica

\section{A B S T R A C T}

This study presents new field and petrological data on carbonated metasomatic rocks from the lawsonite-eclogite units of Alpine Corsica. These rocks form along major, slab-scale lithological boundaries of the subducted Alpine Tethys plate. Our results indicate that a large variety of rocks ranging from metamafic/ultramafic to metafelsic can react with carbon-bearing fluids, leading to carbon sequestration at high-pressure conditions. The process of carbonation includes both replacement of silicates by high-pressure carbonate, and carbonate veining. The field, microstructural and mineralogical data strongly suggest that the metasomatism was mediated by the infiltration of external fluids of mixed origin, including both mafic/ultramafic and metasedimentary sources. Our results support the following three-step evolution: (i) Release of aqueous fluids by lawsonite and/or antigorite breakdown at depth; (ii) Fluid channelization along the base of the metasedimentary pile of the subducted lithospheric plate and related reactive fluid flow leading to carbonate mineral dissolution; (iii) Further interactions of the resulting carbon-bearing fluids with slab-forming rocks at depths of ca. $70 \mathrm{~km}$ and carbonation of pre-existing silicaterich lithologies. This study highlights the importance of carbonate-bearing fluids evolving along down-T, down$P$ paths, such as along slab-parallel lithological boundaries, for the sequestration of carbon in subduction zones, and suggests that similar processes may also operate in collisional settings.

\section{Introduction}

Subduction zones control an important part of the carbon cycle by regulating the exchanges between shallow and deep carbon reservoirs (e.g., Hammouda, 2003; Hayes and Waldbauer, 2006; Dasgupta and Hirschmann, 2010; Dasgupta, 2013; Evans, 2012; Poli, 2015). The amount of carbon that enters subduction zones is currently estimated to range from 40 to $66 \mathrm{Mt} \mathrm{C/yr} \mathrm{(Kelemen} \mathrm{and} \mathrm{Manning,} \mathrm{2015).} \mathrm{This} \mathrm{car-}$ bon is dominantly hosted in carbonate minerals present in both sediments and altered oceanic crust and mantle rocks (Plank and Langmuir, 1998; Alt and Teagle, 1999; Jarrard, 2003; Plank, 2014).

The study of the petrological evolution of subducting carbonatebearing rocks is therefore crucial for the understanding of the global carbon cycle (Kerrick and Connolly, 1998, 2001; Molina and Poli, 2000; Gorman et al., 2006). Subducted carbonate may experience different mechanisms of recycling, which are in most cases enhanced by opensystem conditions and infiltration of external fluids. These mechanisms include processes related to the reactivity between carbonates and silicates (e.g. decarbonation reactions; Kerrick and Connolly, 1998, 2001;

\footnotetext{
* Corresponding authors.

E-mail addresses: francesca.piccoli@gmail.com (F. Piccoli), alberto.vitale-brovarone@upmc.fr (A. Vitale Brovarone).
}

Gorman et al., 2006), processes related to carbonate solubility in aqueous fluids (e.g. carbonate dissolution; Frezzotti et al., 2011; Ague and Nicolescu, 2014), processes of carbonate reduction (to either solid or fluid reduced phases; Malvoisin et al., 2011; Galvez et al., 2013; Vitale Brovarone et al., 2017), and melting (Schneider and Eggler, 1986; Hammouda, 2003; Poli, 2015). Several works have focused on the mechanism that can release carbon from subducting slabs and transfer it to shallower reservoirs, most notably the mantle wedge and volcanic arcs above subduction zones. Decarbonation reactions releasing $\mathrm{CO}_{2}$ are expected to be particularly efficient at forearc conditions (Kerrick and Connolly, 1998, 2001; Gorman et al., 2006), whereas carbonate dissolution has been identified as a major process for carbon release occurring at forearc and possibly subarc depths (Frezzotti et al., 2011; Ague and Nicolescu, 2014). Accounting for the ensemble of these processes, Kelemen and Manning (2015) estimate deep carbon fluxes from the subducting slab into the shallow mantle of 4 to $60 \mathrm{Mt} \mathrm{C} / \mathrm{yr}$. Accordingly, the authors suggest that potentially most subducted carbon (40 to 66 $\mathrm{Mt} \mathrm{C} / \mathrm{yr}$ ) is released from the slab into deep fluids.

Conversely, much less is known regarding the reactivity of carbonbearing fluids, generated by decarbonation/dissolution processes, with silicate rocks in the subducting slab. Equivalent processes are known at low-pressure conditions in both oceanic and on-land settings, where they can sequestrate significant amounts of carbon, including 
atmospheric $\mathrm{CO}_{2}$ (e.g. Kelemen and Matter, 2008). In HP metamorphic settings, recent studies on the exhumed eclogite-facies units of Alpine Corsica and the Western Alps report that, during flow, carbon-bearing fluids can be extremely reactive with mafic and ultramafic rocks and lead to high-pressure (HP) rock carbonation (Piccoli et al., 2016; Scambelluri et al., 2016). HP rock carbonation is a newly discovered process of carbon sequestration that can contribute to counterbalance carbon fluxes due to mobilization processes (both decarbonation and dissolution), with potential large-scale implications for the global carbon cycle (Piccoli et al., 2016). The identification of HP carbonation in exhumed metamorphic terranes, however, may be challenging owing to the absence of diagnostic mineral assemblages and the effect of deformation and late metamorphic overprinting.

In this contribution, we present a detailed field and petrological dataset for several occurrences of carbonated metasomatic rocks in the lawsonite eclogite-facies terrains of Alpine Corsica (France). The aim of this work is threefold. Firstly to provide an exhaustive picture of the nature and diversity of these carbonated metasomatic products and their protolith rocks. Secondly, elucidate general petrological and geochemical features characterizing carbonate metasomatic processes at HP conditions in subduction zones. Lastly, discuss the fluid composition and sources. A conceptual model of large-scale reactive fluid flow is then proposed based on the field, petrological, and geochemical observations in order to better assess the impact of this process on the carbon inventory in subduction zone reservoirs.

\section{Geological setting}

\subsection{Geology of Alpine Corsica and the San Petrone unit}

Alpine Corsica occupies the northeastern part of the island of Corsica (France) and is a segment of the Alpine orogenic system (Jolivet

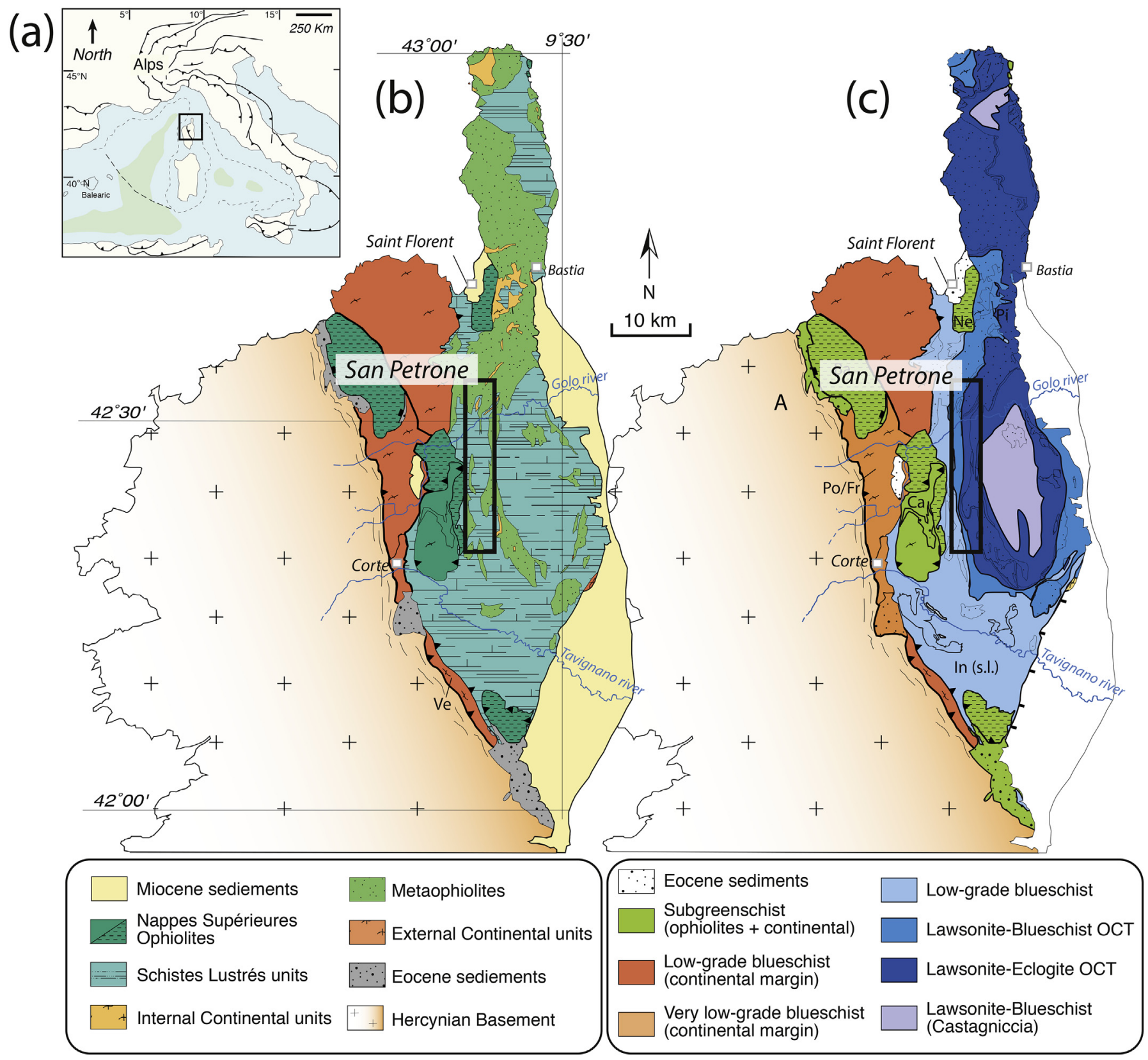

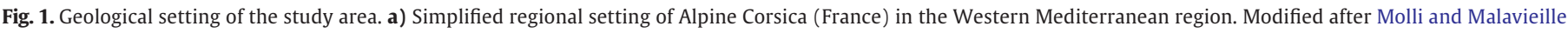

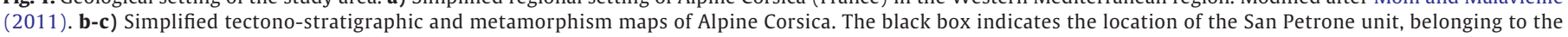
lawsonite-eclogite terrains. Modified after Vitale Brovarone et al. (2014a). 


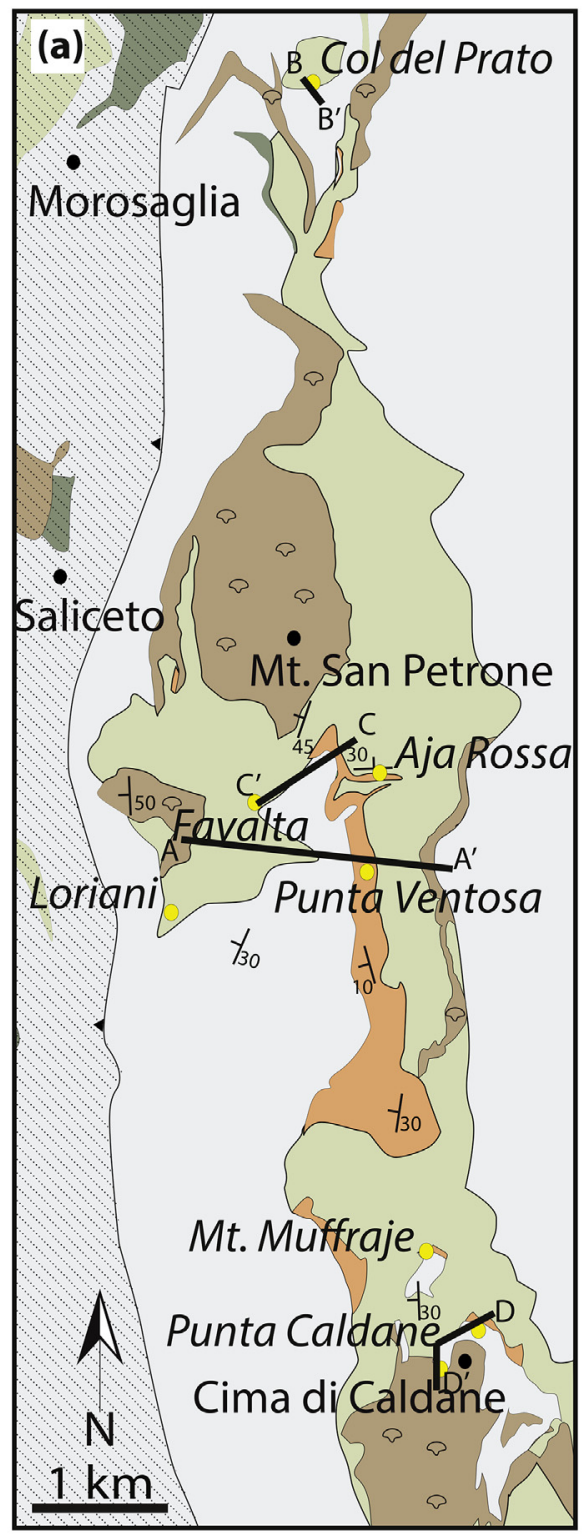

Mesozoic metasediments:

a) Early post-rift cover; b) Post-rift cover Continental-basement rocks

\begin{tabular}{|l|l|}
\hline Metabasalt & Blueschist Zone \\
\hline & Metagabbro \\
$\square$ & Eclogitic Zone \\
\hline & Serpentinite $\quad-\begin{array}{l}\text { Metasomatized } \\
\text { contact }\end{array}$ \\
\hline
\end{tabular}

(b) $\mathrm{A}$

$A^{\prime}$

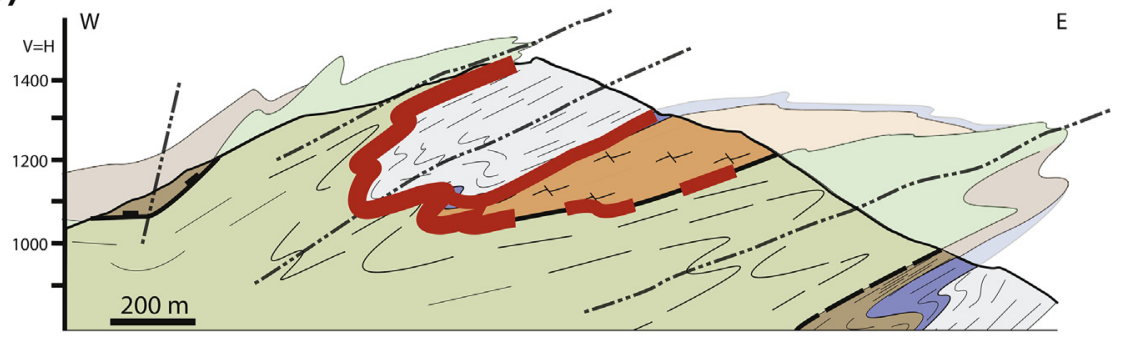

(c)

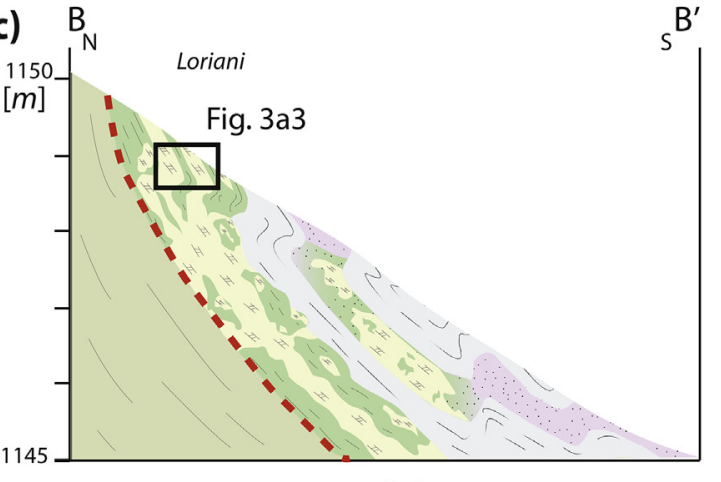

$s^{B^{\prime}}$

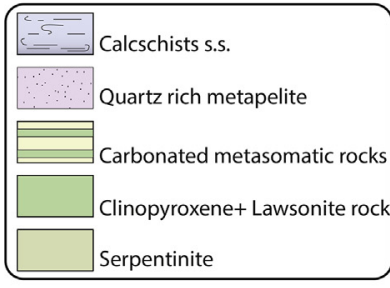

(d)

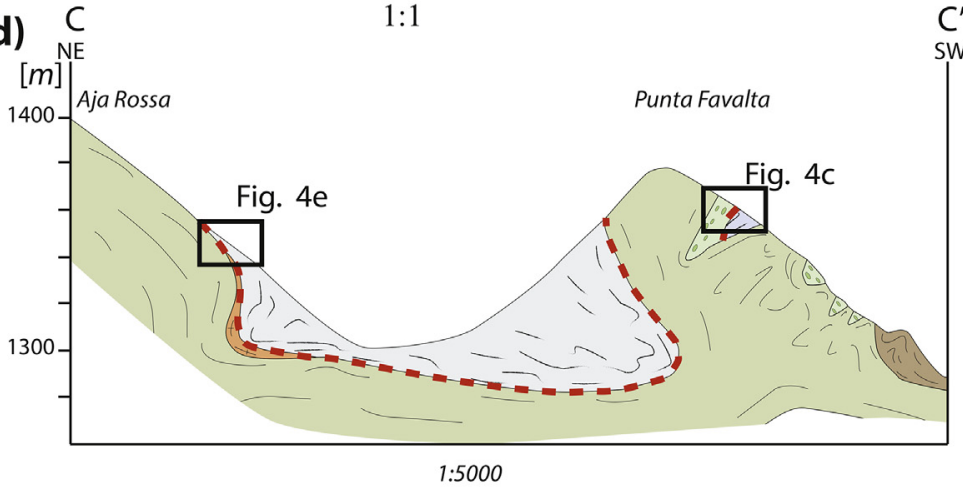

(e) $\underset{N E}{D} \quad S W, N \quad D^{\prime}$

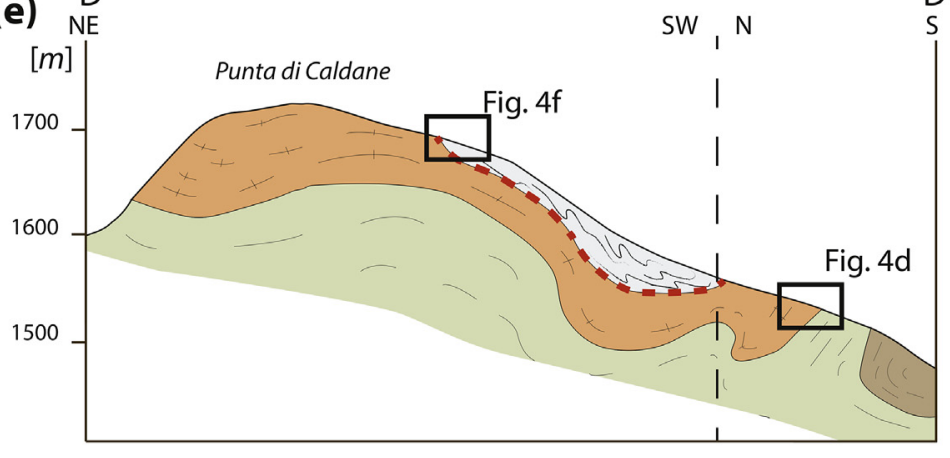

1:5000

Fig. 2. a) Simplified geological map of the San Petrone unit. Modified after Vitale Brovarone et al. (2014a). Outcrops location is indicated by yellow dots. Black solid lines indicate the orientation of geological cross sections. b,c,d,e) Geological cross sections. Dashed red line indicates metasomatized lithological boundaries. (For interpretation of the references to colour in this figure legend, the reader is referred to the web version of this article.)

Fig. 3. Interpretative logs of the metasomatized lithological contacts and relatively outcrop images. In each log, the left side represents the unaltered tectonostratigraphic sequence (observed or reconstructed), whereas the right side is the metasomatic equivalent as observed in the field. a) Serpentinite-early post rift metasediments contact and metasomatic equivalent. a1) Unaltered early post-rift metasediments sequence composed by alternating quartz-rich and carbonate rich layers. a2) Preserved quartz-blue amphibole bearing metachert. a3) Banded carbonated metasomatic rock from Col del Prato area. a4) Preserved metachert level in carbonated metasomatic rock. Note that preserved metachert is pinkish colored while the border is green indicated a partial rock transformation. b) Serpentinite-thin continental crust sliver contact. Note that in the metasomatic equivalent, marbles, veins and crack-seals occur. b1) Pre-Alpine paragneiss. b2) Leucocratic dyke intruding a paragneiss (Photo from Vitale Brovarone et al., 2011a). b3) Omphacite + carbonate vein. b4) Fresh cut of a banded carbonated metasomatic rock cut across by a carbonate + lawsonite vein (Mt. Muffraje area). c) Serpentinite-thick continental crust sliver contact. c1) Ultramafic nodule with ankerite in marble level (Punta Ventosa area). c2) Orthogneiss. c3) Detail of a quartz, blue amphibole bearing carbonated metasomatic rock with metasomatized ultramafic nodules (Punta Caldane area). c4) Detail of the metasomatic rind at the base of an orthogneiss sliver in contact with the serpentinite (west of Punta di Caldane): the lowermost part of the metasomatic rind displays pervasive carbonate veins, discordant to the rock foliation. Mineral abbreviations from Kretz (1983). (For interpretation of the references to colour in this figure legend, the reader is referred to the web version of this article.) 


\section{rocks}
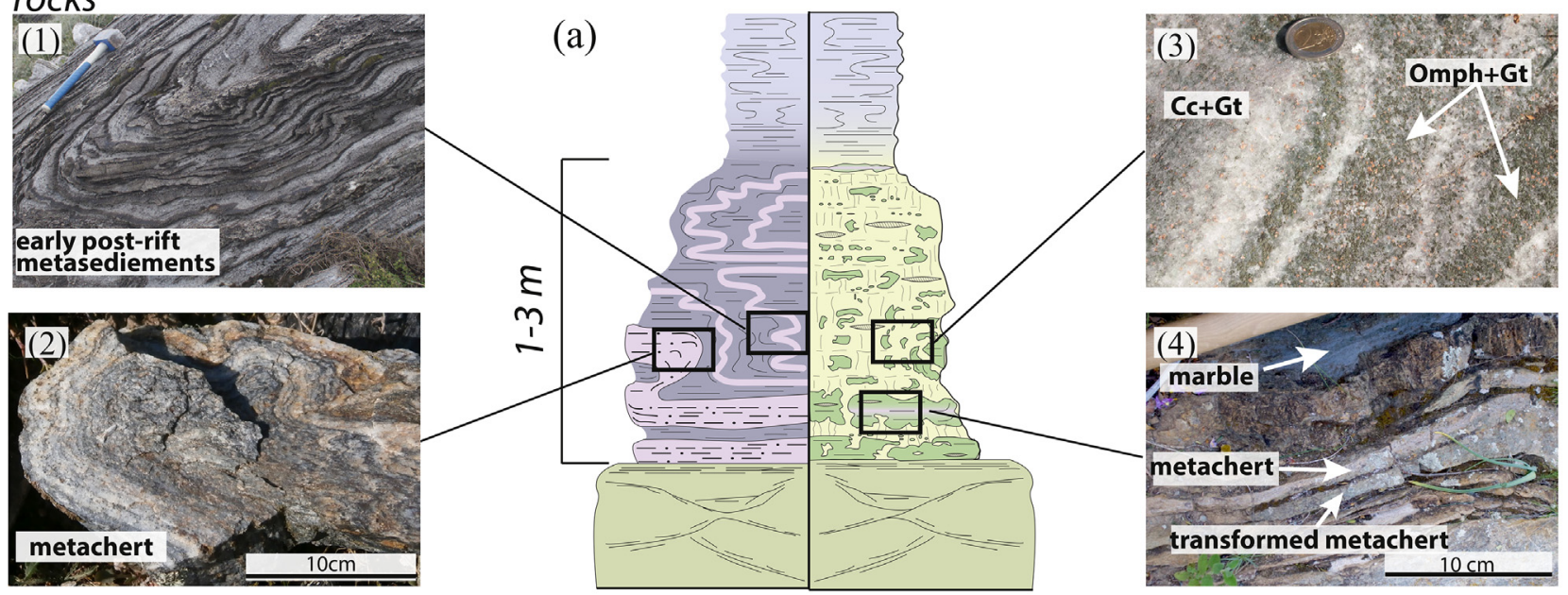
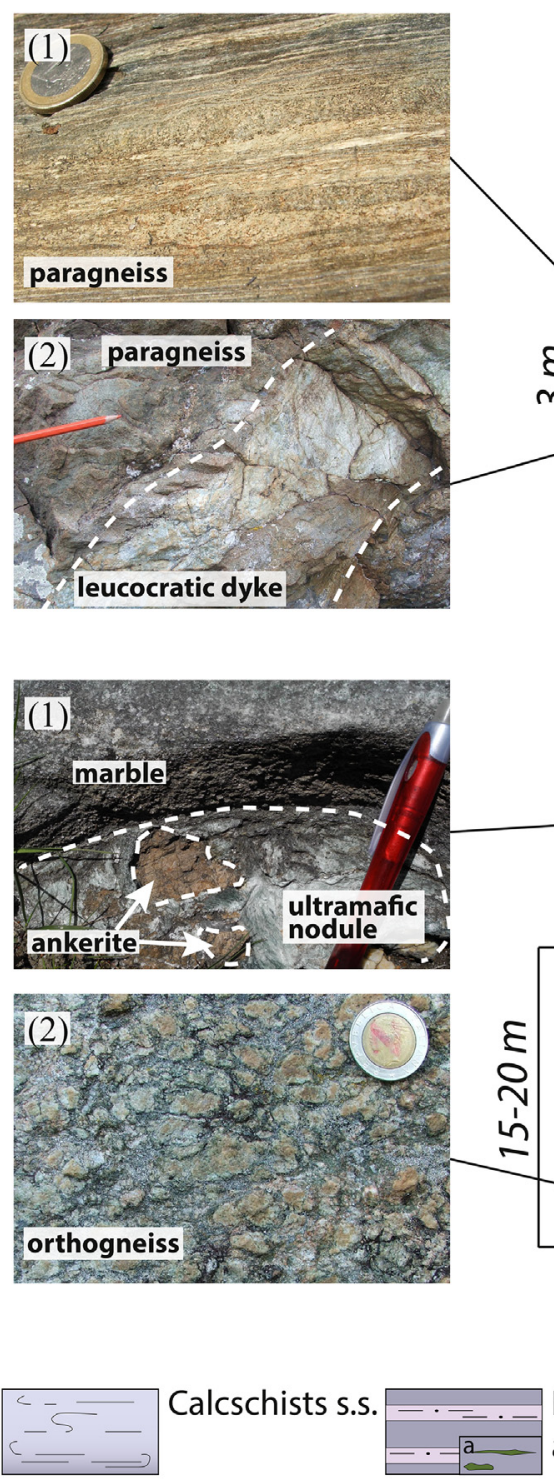

(c)
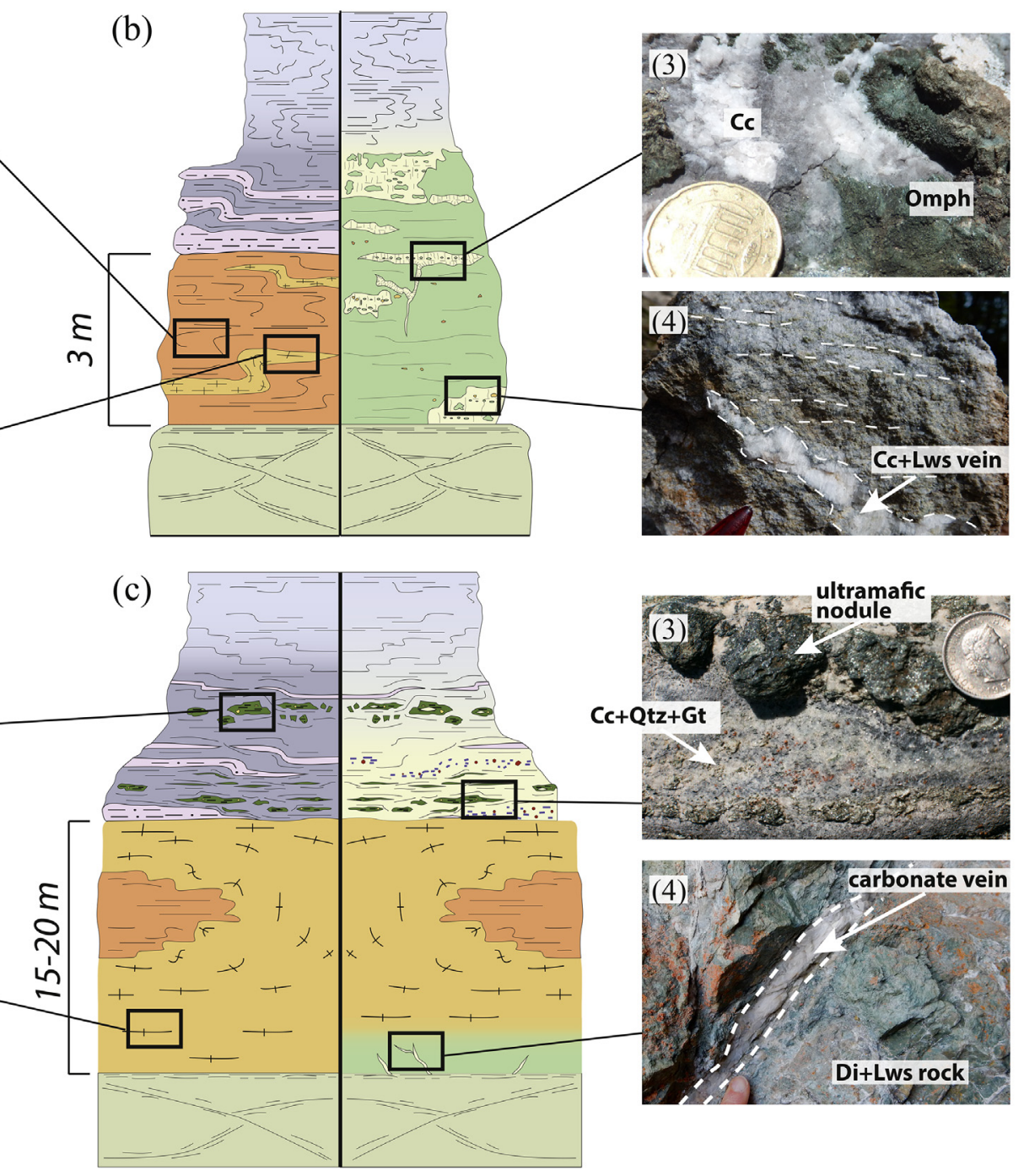

Calcschists s.s.

Diopside+lawsonite rock (Stage\#1 metasomatism) Early post-rift metasediments
a) Ultramafic chaotic sequence a) Paragneiss b) Orthogneiss $\begin{array}{lll}\cdots \cdots= & \text { Quartz, blue amphibole bearing } \\ \text { carbonated matesomatic rocks }\end{array}$ Serpentinite 
et al., 1991; Molli and Malavieille, 2011; Fig. 1a). The belt is subdivided into three domains (see Vitale Brovarone et al., 2013 for review): 1) the continent-derived units; 2) the Schistes Lustrés complex; and 3) the uppermost thrust sheets (Nappes Supérieures) (Fig. 1b). Altogether, these units were thrust over the western and southern part of the island, which largely escaped the Alpine subduction and orogenesis. The Schistes Lustrés complex consists of remnants of subducted Mesozoic slowspreading oceanic and passive margin lithosphere of the Tethys Ocean, and shows lithostratigraphic features analogous to those of the eclogite-facies units exposed in the Piemonte Zone of the Western Alps (e.g. Queyras/Combin/Monviso/Rocciavré/ Zermatt-Saas area; Lagabrielle and Lemoine, 1997; Lombardo et al., 2002; Vitale Brovarone et al., 2014a). The Schistes Lustrés complex forms a N-S antiformal stack with metamorphic grade increasing from the top to the bottom, with the exception of the lowermost structural unit (Castagniccia unit, Fig. 1c). The peak metamorphic grade varies from subgreenschist-facies conditions of about $300{ }^{\circ} \mathrm{C}$ and $0.4 \mathrm{GPa}$ to lawsonite blueschistand lawsonite eclogite-facies conditions of $500-550{ }^{\circ} \mathrm{C}$ and 2.3 GPa (e.g. Fournier et al., 1991; Ravna et al., 2010; Vitale Brovarone et al., 2013).

In this study, we focus on the San Petrone unit, which belongs to the lawsonite eclogite-facies terrains (Vitale Brovarone et al., 2011a) (Fig. 2a). The San Petrone unit is interpreted to represent a coherent segment of subducted Jurassic hyper-extended passive margin or oceancontinent transitional lithosphere (Vitale Brovarone et al., 2011a; Beltrando et al., 2014). The unit consists of a basal body of serpentinized mantle peridotites overlain by a laterally variable lithostratigraphy comprising: i) slivers of continental basement rocks; ii) pillow metabasalts; and iii) Mesozoic metasedimentary rocks (Fig. 2b). By analogy with present-day passive margins, the basal serpentinized peridotites are interpreted as sub-continental mantle rocks exhumed and altered on the seafloor during Jurassic (hyper)extension (Manatschal, 2004; Beltrando et al., 2014 and references therein; Picazo et al., 2016). Evidence of these events is also well documented in the San Petrone unit, such as scattered bodies of ophicarbonates found along the top of the serpentinite testifying for mantle alteration along a paleo-seafloor (Vitale Brovarone et al., 2011a). Metagabbros are rare in this unit and are found as small pods within the serpentinite. The continental basement slivers lie directly upon the serpentinite (Fig. 2a,b,c-d), and contain both orthogneiss and carbonate-free paragneiss. These continental basement slivers are interpreted as continental extensional allochthons emplaced on top of the exhumed mantle substratum during the hyperextension of the continental margin (Vitale Brovarone et al., 2011a; Beltrando et al., 2014). Metabasalts form large bodies (Fig. 2a) with structural position equivalent to the continental slivers, and never underlie or overlie them. Mesozoic metasedimentary rocks variably overlie the serpentinite ( \pm ophicarbonate), the continental slivers, and/or the metabasalts (Fig. 2a,b). The base of the Mesozoic metasedimentary suite comprises the original basal unconformity of marine sediments in the Tethys basin (Vitale Brovarone et al., 2011a; Beltrando et al., 2014) and, therefore, was a major lithological boundary during the Alpine subduction. The Mesozoic metasediments can be divided into early post-rift and post-rift metasediments (Fig. 2b). The first group consists of metacherts (likely radiolarian metacherts) and marbles of inferred Jurassic sedimentary age; the second group mainly includes calcschists sensu stricto, i.e., pelitic layers alternating with carbonate-rich layers of Cretaceous sedimentary age (Vitale Brovarone et al., 2011a). This composite tectonostratigraphic sequence is folded by a series of large $(\mathrm{km}$ in length) N-S non-cylindrical anticlines and synclines that locally overturn the overall upright tectonostratigraphy (Fig. 2b). Because of the non-cylindrical folds, the entire lithostratigraphy is affected by local and discontinuous synformal and antiformal structures with $\mathrm{N}-\mathrm{S}$ trending fold axes (Fig. 2b,c,d). The whole tectonolithostratigraphic suite of the San Petrone unit underwent consistent peak metamorphic conditions of about $500-550{ }^{\circ} \mathrm{C}$ and 2.2-2.4 GPa (Vitale Brovarone et al., 2011b) in the Late Eocene (U-Pb zircon 34 Ma, Martin et al., 2011; Lu-Hf garnet, Vitale Brovarone and Herwartz, 2013).

\subsection{Fluid-rock interaction and metasomatism in the San Petrone unit}

Previous studies have documented rocks affected by strong fluidrock interactions and metasomatism localized along the contact separating the serpentinized mantle rocks and the overlying lithologies (Vitale Brovarone et al., 2011a, 2014b; Martin et al., 2011; Piccoli et al., 2016) (Fig. 2b-e). Two successive metasomatic stages were identified: (i) A first event characterized by fluid-mediated lawsonite-diopside crystallization (Stage\#1 metasomatic rocks) and constrained to prograde-to-peak metamorphic conditions (2$2.2 \mathrm{GPa} ; 500-550{ }^{\circ} \mathrm{C}$ ) by petrological and geochemical data and U$\mathrm{Pb}$ zircon geochronology (Martin et al., 2011; Vitale Brovarone et al., 2014b and references therein); (ii) A second event characterized by carbonate metasomatism and formation of carbonate-rich rocks (Stage\#2 metasomatic rocks; Piccoli et al., 2016). The second event occurred through the interplay of fluid-silicate interactions, hereafter termed silicate carbonation, and veining. Mineral assemblages, including coexisting carbonate + omphacite + garnet, and stable isotope geothermometry $\left(493 \pm 30^{\circ} \mathrm{C}\right)$ coupled with previous P-T-paths (Vitale Brovarone et al., 2011b) constrain this second event to near peak metamorphic conditions (Piccoli et al., 2016). Of particular interest for this study are Stage\#2 carbonated metasomatic rocks, for which we report herein new field and petrological data.

\section{Tectonostratigraphic occurrence of carbonated metasomatic rocks}

Carbonated metasomatic rocks in the San Petrone unit occur along three main types of regional lithological interfaces (Fig. 2), which are described in the following together with their most notable structural and lithological features. The reconstruction of the premetasomatism metasedimentary sequences was done by integrating field and petrological observations from our survey and previous studies. Fig. 3 summarizes the main field lithostratigraphic observations by means of interpretative tectonostratigraphic logs and representative field images.

\subsection{Serpentinite-Mesozoic metasediments}

This regional lithological interface crops out several times over about $13 \mathrm{~km}$ (Fig. 2a). The best examples of metasomatism along this type of lithological interface are exposed in the localities of Col del Prato, Punta Favalta and Loriani (Figs. 2a,c; 3a and 4a,b,c). In these zones, the serpentinite below the contact is massive to foliated. Only the very top centimeters of the serpentinite exhibit a marked schistosity parallel to the contact with the overlying rocks; these schistose zones are also more weathered than unfoliated serpentinite. At the regional scale, relicts of the Mesozoic metasedimentary rocks overlying the serpentinite and unaffected by metasomatism commonly consist of quartz-rich, carbonate-free layers alternating with impure marbles (Fig. 3a1,a2), followed upward by calcschists sensu stricto (pelitic layers with more or less abundant carbonate layers). The quartz-rich layers, commonly metacherts (Fig. 3a2), are continuous and range in thickness from a few $\mathrm{cm}$ to about $1 \mathrm{~m}$, and are frequently observed at the base of the metasedimentary sequence (first $3 \mathrm{~m}$ above the contact). Metacherts commonly contain Mn-rich minerals suggesting transformations of Mn-bearing radiolarian metacherts typical of the lowermost portion of the Tethyan Mesozoic sedimentary cover sequences preserved in this unit (Vitale Brovarone et al., 2011a and references therein). The metasedimentary rocks are affected by polyphase deformation leading 

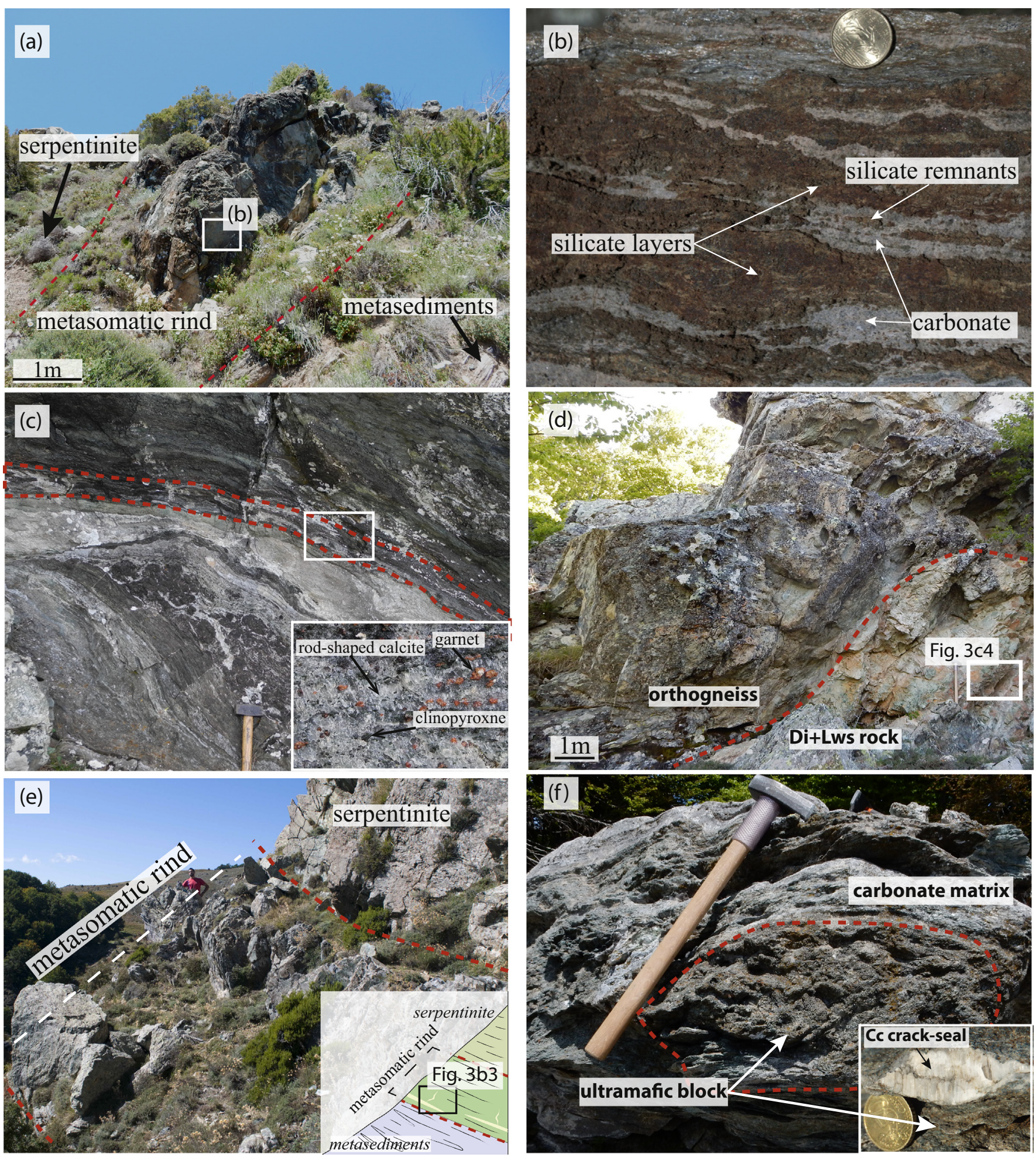

Fig. 4. Outcrop of carbonated metasomatic rocks along different lithological contacts. a) Loriani outcrop. Here the metasomatic rind width ranges between $1 \mathrm{~m}$ and $2.5 \mathrm{~m}$. b) Detail of Loriani outcrop showing the heterogeneous carbonation of the silicate rock. c) Shear zone in the metasomatized contact in Punta Favalta area. The dashed red lines indicate the carbonated metasomatic rock level, the detail of which is reported in the white box. d) Metasomatic rind on the orthogneiss in contact with serpentinite nearby Punta Caldane. e) Aja Rossa outcrop and simplified geological cross section (modified after Vitale Brovarone et al., 2014b).f) Outcrop in Punta Caldane area: mafic block embedded in carbonate matrix. A detail of a carbonate crack-seal opening within the mafic block is reported in the white box. (For interpretation of the references to colour in this figure legend, the reader is referred to the web version of this article.)

to non-cylindrical and disharmonic folding and a marked composite schistosity (Fig. 3a1) that locally resulted in boudinage of the quartzrich layers.

The contact between the serpentinite and the metasediments is commonly affected by a strongly asymmetric metasomatic front formed at the expense of the lower part of the metasedimentary pile overlying the serpentinite (first 1-3 m), and with no marked evidence for metasomatism in the serpentinite (Figs. 3a3,a4, 4b; Martin et al., 2011; Vitale Brovarone et al., 2014b; Piccoli et al., 2016). The metasomatic halo consists of both diopside-lawsonite-rich rocks (Stage\#1 metasomatism) 
and carbonated metasomatic rocks (Stage\#2 metasomatism). Field observations attest to the relative chronology of the two metasomatic events, with Stage\#2 carbonation partially replacing Stage\#1 metasomatic rocks. These two metasomatic end-members (diopside-lawsonite and carbonated metasomatic rocks) are observed at various scales with two main modes of occurrence. In some cases the two rock types form a layered structure that mimics (Fig. 3a2, a4) the structure of pristine metasedimentary sequences composed of folded impure marbles and metachert layers (Fig. 3a1,a3). Some outcrops show partial replacement of the protolith metasedimentary rocks by the metasomatic assemblages. The most remarkable example was observed in the Loriani outcrop (Figs. 2a, 4a), where a progressive transformation of a former metachert layer into diopside-lawsonite-rich rocks can be clearly seen on the outcrop (Fig. 3a4). The diopside-lawsonite domains are then replaced by carbonate. This process leads to heterogeneous consumption and segmentation of the silicate-rich layers of the initial metasedimentary sequence (Fig. 4b). The latter process is commonly mediated through processes of fracturing and brecciation of the Stage\#1 rocks and formation of carbonate crack-seals, along with chemical replacement of silicates by carbonate (Piccoli et al., 2016). Field and microstructural observations indicate that both metasomatic events post-dated the main regional-scale folding event.

In the Punta Favalta area, a $\sim 8 \mathrm{~m}$ thick sequence of variably metasomatized and intensely deformed rocks is found atop the regional serpentinite. Here, the serpentinite basement is intensely folded and capped by ophicarbonates. A small lens of metasediments is sandwiched in a tight, recumbent syncline. The outcrop is located in the overturned limb of the fold (Fig. 2d). The rocks overlying the serpentinite are intensely metasomatized and affected by strong deformation along a main shear zone. Fig. 4c shows the shear zone between less deformed lawsonite-rich rocks and highly strained carbonated metasomatic rocks.

\subsection{Serpentinite-continental basement rocks}

Metasomatism also affected initially carbonate-free, pre-Alpine continental basement rocks resting on top of the serpentinite (Figs. $2 \mathrm{~b}, 3 \mathrm{~b}$, c). The extent of metasomatism most commonly inversely correlates with the thickness of the continental basement slivers. The most notable examples of metasomatism in this structural setting are found in the area between Punta di Caldane, Monte Muffraje and Aja Rossa (Fig. 2a, $\mathrm{d}, \mathrm{e})$. In the southern part of the study area (Punta di Caldane; Fig. 2e), a 15-20 m thick (minimum thickness) sliver of continental basement rock crops out discontinuously and forms patches of variable thickness. In the vicinity of Punta di Caldane, this body mainly consists of orthogneiss ( \pm discontinuous paragneiss lenses; Figs. 2e, 3c2, 4d) overlying the serpentinite. The uppermost tens of $\mathrm{cm}$ of the serpentinite nearby the contact show a marked schistosity parallel to the contact and no alteration halos have been observed. Above the contact, the first $2 \mathrm{~m}$ of rock consist of Stage\#1 diopside-lawsonite metasomatic rock formed at the expense of the orthogneiss, as indicated by the primary structure of the orthogneiss preserved in the metasomatic halo. In the lowermost part of the metasomatic rind, several carbonate veins cut across the metasomatized orthogneiss (Fig. 3c4). The veins reach about $2 \mathrm{~cm}$ in thickness and have sharp contacts, with no alteration selvage observable in the field. No evidence for carbonation by replacement of former silicates was observed here.

The same contact is exposed in the Monte Muffraje area. Here, a 2 to 3 m-thick patch of metasomatic rocks cap the serpentinite, and are followed upwards by unaltered Mesozoic calcschists. The contact between the metasomatic rind and the serpentinite is parallel to the regional schistosity and dips gently to the west. As for the previous cases, the serpentinite does not show marked evidence for strong fluid-rock interactions. In the field, the distinction between metasomatized pre-Alpine and Mesozoic rocks cannot be easily made owing to the outcrop conditions and the pervasive metasomatism. The metasomatic rind consists of both Stage\#1 and Stage\#2 metasomatic rocks. Stage\#1 rocks dominantly consist of diopside and lawsonite, and occur as dismembered, partially corroded patches embedded in a Stage\#2 carbonate-rich matrix (Fig. 3b4). Stage\#1 domains preserve a weak foliation inherited from the protolith. In the Stage\#2 rocks, carbonate in most cases forms rods oriented at high-angles to the regional schistosity. Carbonate and carbonate + lawsonite veins, often with crack-seal texture, are widespread and locally discordant to the regional foliation (Fig. 3b4). The orientation of the foliation in the patches of Stage\#1 rocks is consistent at the outcrop scale (i.e. no clast rotation) and indicates that carbonate precipitation occurred statically.

As in the previous case, in the Aja Rossa area, a thin (a few meters) slice of continental basement rocks is extremely metasomatized (Fig. 4e). The metasomatic rind in this outcrop extends over the continental material and also affects the overlying Mesozoic metasediments for a total thickness of ca. $8 \mathrm{~m}$ (Martin et al., 2011; Vitale Brovarone et al., 2014b).

\subsection{Continental crust-Mesozoic metasediments}

Metasomatic rocks and HP carbonation were also observed along the top of the pre-Alpine continental basement rocks in contact with Mesozoic metasedimentary rocks. The two most notable examples crop out in the area of Punta di Caldane and to the East of Punta Ventosa (Fig. 2a,e). In the vicinity of Punta di Caldane, Mesozoic metasedimentary rocks cap a 15-20 m thick sliver of continental basement rocks, which in turn overlie the basal serpentinite (Section 3.2). In the first $5 \mathrm{~m}$ above the contact with the orthogneiss, a chaotic ensemble made of deformed clasts/blocks of mafic/ultramafic rocks dominated by green amphibole + chlorite ( \pm lawsonite, \pm ankerite), dispersed in a carbonate-rich matrix (Figs. 3c1; 4f) (hereafter, carbonated mafic/ ultramafic rocks) is found. Some clasts are intensely strained and form discontinuous layers, with dimensions ranging from a few $\mathrm{cm}$ to ca. $50 \mathrm{~cm}$ in diameter. Ca-carbonate crack-seals associated within green amphibole-chlorite lenses are also observed (Fig. 4f). Furthermore, hydraulic breccias composed of blocks of metasomatic origin (diopside + lawsonite) sealed by rod-shaped carbonate are locally observed within the first few meters of the sequence. Quartz-rich rocks overlie the chaotic sequence of carbonated mafic/ultramafic rocks. No unaltered protolith rocks with comparable structural features were found, with the exception of a small body of brecciated and carbonated serpentinites (ophicarbonates) about $\sim 150 \mathrm{~m}$ from the Punta Ventosa outcrop. The metasedimentary sequence becomes more homogeneous and dominated by calcschists from $\sim 5 \mathrm{~m}$ above the contact with the continental sliver.

In the region of Punta Ventosa (Fig. 2a), carbonated mafic/ultramafic rocks overlying the continental crust are also present. In this locality, impure marble layers with abundant deep green clinopyroxene, blue amphibole, garnet, and minor quartz (Fig. 3c3), overlie the carbonated mafic/ultramafic rocks. This kind of carbonated rock never occurs in the metasedimentary sequence far from major lithological interfaces, where only monotonous rocks such as calcschists are found.

The heterogeneity of the chaotic sequence in these two areas makes the identification of individual metasomatic events and the reconstruction of a pre-metasomatism tectonostratigraphy more challenging than the previous cases.

\section{Methods}

\subsection{Scanning electron microscopy and electron microprobe}

Petrographic thin sections were carbon coated for scanning electron microscopy (SEM). Observations were performed at a working distance of $7.5 \mathrm{~mm}$ using a Zeiss Ultra 55 field emission gun SEM operated at 15 $\mathrm{kV}$ with a $120 \mu \mathrm{m}$ aperture. Backscattered electron (BSE) mode was used to investigate chemical heterogeneities using an Angle Selective Backscattered Detector (AsB) or an Energy Selective Backscattered 
Table 1

Summary table reporting mineral paragenesis of the study rocks.

\begin{tabular}{|c|c|c|c|c|c|}
\hline Locality & Interface & Protolith & Stage\#1 & Stage\#2 & Late stages \\
\hline Loriani & Serpentinite/ Mesozoic metasediments & Metachert, Calcschists & Di, Lws & Cc, Agt, $( \pm \mathrm{Gt})$ & Pmp, Ep, Ab \\
\hline Col de Prato & Serpentinite/ Mesozoic metasediments & Metachert, Calcschists & Di, (Lws?) & Cc, Omph, Gt & Ab, Phg \\
\hline Punta Favalta & Serpentinite/ Mesozoic metasediments & Metachert (?) & Ep, Rieb, Qtz, Hem, Deer & Cc, Agt, Gt, Qtz, Hem, Deer & - \\
\hline Aja Rossa & $\begin{array}{l}\text { Serpentinite / pre-Alpine HT continental } \\
\text { rocks / Mesozoic metasediments }\end{array}$ & $\begin{array}{l}\text { Paragneiss (?), Calcschists (?), } \\
\text { Metachert (?) }\end{array}$ & Di, Lws & $\mathrm{Cc} / \mathrm{Cc}+\mathrm{Omph}$ & Phg \\
\hline Muffraje & $\begin{array}{l}\text { Serpentinite/ pre-Alpine HT continental } \\
\text { rocks / Mesozoic metasediments }\end{array}$ & Paragneiss, Orthogneiss, Metachert (?) & Di, Law, \pm Gt & Cc, Omph, Gt, (Lws?), (Qtz) & Phg \\
\hline Punta Caldane & $\begin{array}{l}\text { Pre-Alpine HT continental rocks / } \\
\text { Mesozoic metasediments }\end{array}$ & Ultramafic (?) & Act, Chl, (Lws?) & Cc, Agt, Gt, Qtz & Gln, Phg \\
\hline Punta Ventosa & $\begin{array}{l}\text { Pre-Alpine HT continental rocks / } \\
\text { Mesozoic metasediments }\end{array}$ & Ultramafic (?) & Di, Act, Chl, (Lws?) & Cc, Omph-Agt, Gt, Qtz & Phg \\
\hline
\end{tabular}

Detector (EsB). Energy dispersive X-ray spectrometry (EDXS) maps were acquired using an EDXS QUANTAX system equipped with a silicon drift detector XFlash 4010 (Bruker). Data were processed with the software Esprit (Bruker). Mineral analyses were performed on a Cameca electron microprobe (either SX-100 or SX Five) (Camparis, Université Paris 6). Common analytical conditions were adopted for spot analyses (15 kV, $10 \mathrm{nA}$, wavelength-dispersive spectroscopy [WDS] mode), using $\mathrm{Fe}_{2} \mathrm{O}_{3}, \mathrm{MnTiO}_{3}(\mathrm{Mn}, \mathrm{Ti})$, diopside $(\mathrm{Mg}, \mathrm{Si})$, orthoclase (Al, K), anorthite ( $\mathrm{Ca}$ ) and albite (Na) as standards. The automated Cameca ZAF procedure was used for quantification. For clinopyroxene, garnet, and amphibole ferric and ferrous iron contents were calculated on the basis of charge balance, using 6,12 and 23 oxygens per formula unit, respectively, and with fixed cations per formula unit: 4,8 and 13 , respectively. All iron was assumed to be $\mathrm{Fe}^{3+}$ for pumpellyite and epidote, and $\mathrm{Fe}^{2+}$ for mica. The water content of hydrous minerals was calculated assuming stoichiometry.

\section{Petrography}

Here we present an overview of the characteristic microstructures of the main rock types studied, including the protolith rocks and their metasomatic equivalents from the three types of tectonostratigraphic settings described in the previous section. Table 1 summarizes the petrological evolution of the study samples during Stage\#1 and Stage\#2 metasomatism by reporting the most characteristic mineral paragenesis for the main metasomatic stages. Mineral modal volumes for the studied thin sections are reported in Table S1, mineral chemistry is described in the next section, and representative analyses are reported in Table S2. Carbonates are always compositionally pure $\mathrm{CaCO}_{3}$, unless otherwise specified. In the matrix, calcite replaces aragonite, whereas fresh aragonite is locally preserved as inclusions in garnet and hematite.

\subsection{Unaltered protolith rocks}

\subsubsection{Mesozoic metasediments}

Relicts of Mesozoic metasediments little or unaffected by metasomatism range from metachert (sample cor16-42d) to quartz-carbonate rich rocks (samples 1cor12-20c and 1cor14-5, Fig. 3a1, a2). In thin section, the first variety displays disjunctive schistosity (Passchier and Trouw, 2005) marked by phengite rich layers and oriented blue amphibole alternating with coarse-grained granoblastic quartz domains (Figs. 5a, 6a).Small euhedral garnets grew in the amphibole-phengite domains (Fig. 6a). The second rock type is characterized by alternating mmthick layers of carbonate and quartz (Figs. 5b, 6b). Euhedral garnet is found in the silicate-rich domains (Fig. 6b). Iron-rich carbonate and opaque minerals form clumps wrapped by phengite, blue amphibole, and epidote (Fig. 5b). Mn-rich epidote is also locally present (1cor145c, Table S1). Calcschists sensu stricto (samples cor13-32 and 1cor1211q) have a marked schistosity defined by phengite flakes embedded in a carbonate + quartz granoblastic matrix. In these samples, accessory phases are chlorite, epidote, opaque minerals, and carbonaceous material, the latter being concentrated in the phengite-bearing domains. Pseudomorphs after lawsonite may be present and consist mainly of white mica, chlorite, and opaque minerals.

\subsubsection{Pre-Alpine gneiss}

Pre-Alpine rocks forming the continental basement slices are polymetamorphic micaschists and metamafic paragneiss intruded by Permian granitoids (now orthogneiss, Fig. 3b1,b2,c2) (Vitale Brovarone et al., 2011a and references therein; Martin et al., 2011). The paragneiss may contain inherited HT garnet as a main distinctive feature (Fig. 6g; Martin et al., 2011), whereas the orthogneiss commonly contains jadeite porphyroblasts (Fig. 3c2). The identification of a pre-Alpine protolith in extremely metasomatized rocks was done based on field relationships, such as transitional mineralogical variations statically overprinting preAlpine basement rocks, or by the identification of the above diagnostic minerals as relict phases.

\subsection{Carbonated metasomatic rocks}

\subsubsection{Serpentinite-Mesozoic metasediments contacts}

Stage\#2 carbonated metasomatic rocks (Piccoli et al., 2016) generally display a $\mathrm{mm}$ to $\mathrm{cm}$-scale banded structure of alternating carbonate-rich and silicate-rich layers (Figs. 3a3; 5c). Carbonate-rich domain contains Ca-carbonate, together with garnet and green-pleochroic clinopyroxene (Table 1). Silicate-rich domain contains diopside and lawsonite (Table 1), together with a variable amount of garnet, and late stage product like green amphibole, quartz, epidote (with allanitic cores), pumpellyite and phengite (Table 1). Whenever present, phengite and amphibole preferred orientation marks the regional foliation. The boundaries between the two types of compositional layers range from sharp to embayed in response to different degrees of interaction between the carbonates and the silicates (Piccoli et al., 2016). Crystal size ranges from $\mu \mathrm{m}$ to $\mathrm{mm}$. Carbonaceous material is locally found in both compositional domains. Carbonate is found as both calcite and fresh aragonite, the latter preserved as inclusions in garnet (Piccoli et al., 2016). Ca-carbonate most commonly forms pseudo-hexagonal rods oriented at high angle to the main rock fabric. Clinopyroxene is a common phase in both the carbonate-rich and silicate-rich portions of the rock, and is commonly present in multiple generations resulting from the successive stages of metasomatism (Stage\#1 and Stage\#2, see also next section for compositional features). In samples 1cor12-20d and 1 cor14-12b, clinopyroxene crystals form either stubby neoblasts or fibrous aggregates (Fig. 6c), both sub-mm in size, and with pale- to deep-green pleochroism. Fibrous aggregates have embayed rims when in contact with the carbonate matrix. In sample 1cor12-20d, clinopyroxene crystals display a marked optical zoning between core and rim. The core, inherited from Stage\#1 metasomatism, is pale green and commonly exhibits extensive corrosion and replacement by Ca-carbonate (Figs. 6c, 7a), whereas the rim -the stable clinopyroxene of Stage\#2 metasomatism - is green pleochroic (omphacite) and is in textural equilibrium with the matrix carbonate (Fig. 6c). Garnet has different habits, from euhedral to poikilitic and 


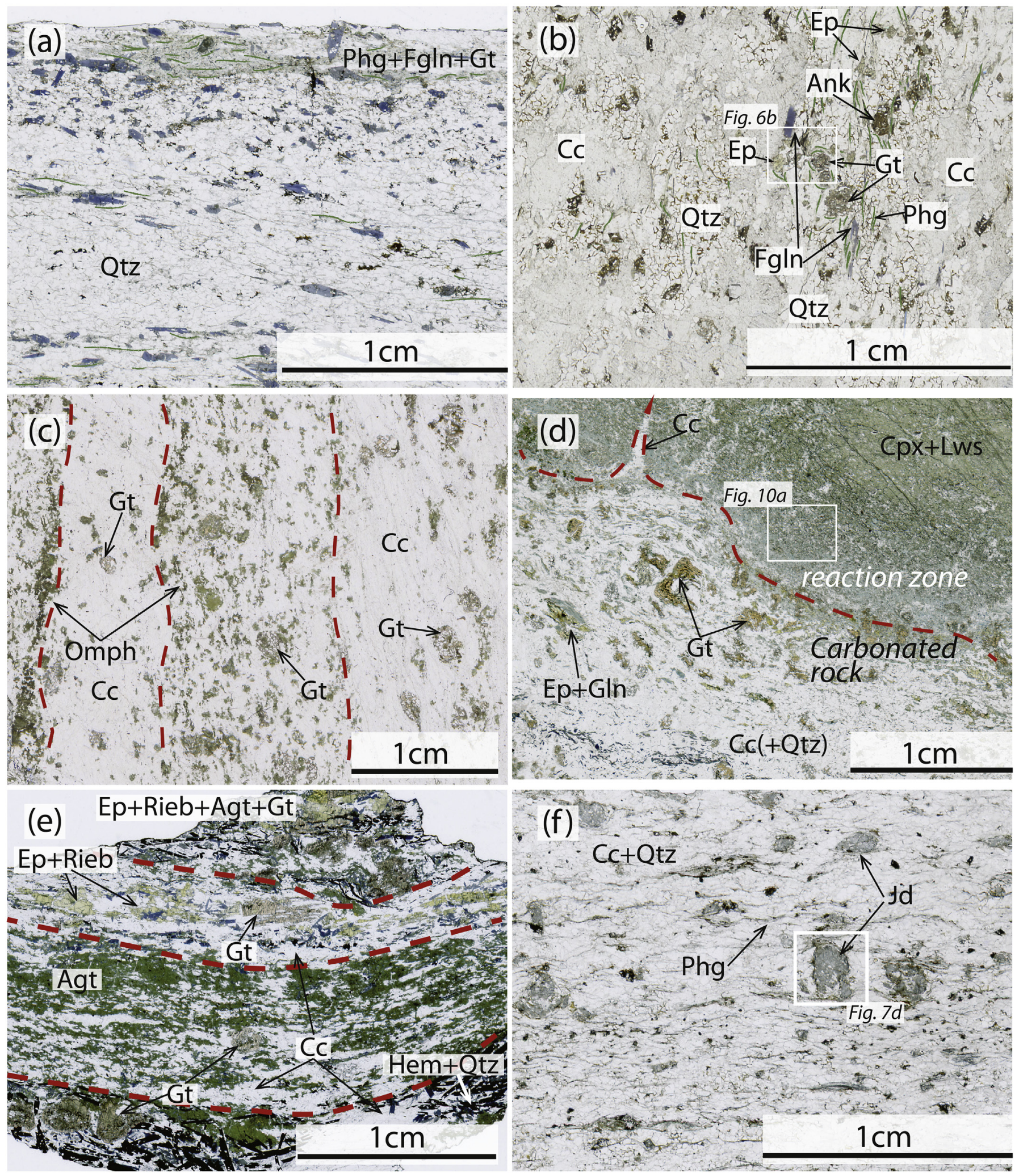

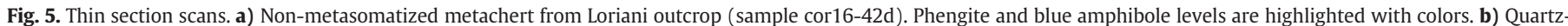

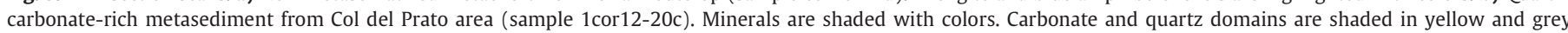

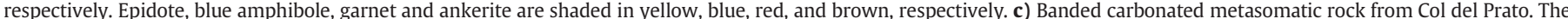

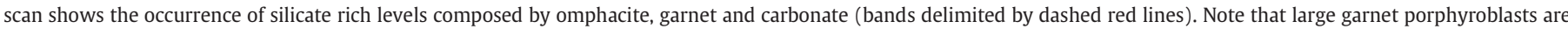

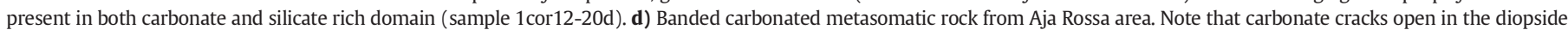
+ lawsonite domain (delimited by the dashed red line). e) Banded carbonated metasomatic rock from the shear zone in Punta Favalta area (sample 1cor14-6a). The dashed red line

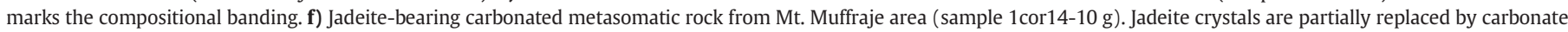

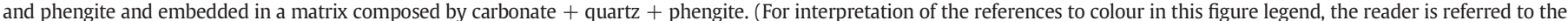
web version of this article.) 
skeletal, and shows strong and variable compositional zonation even by optical microscopy (Fig. 6d,e). Poikilitic garnet contains aragonite/calcite, clinopyroxene, epidote, carbonaceous material, chlorite, and quartz inclusions. In sample 1cor12-20d and cor13-28c, large garnet crystals may have optical zoning with pink core and colorless rim. In other samples, garnet may display sigmoidal or concentric zoning with colorless core and pink rim (Fig. 6d,e). BSE imaging revealed that the garnet compositional zoning can be complex, as shown in Fig. 7e-h. In Fig. 7e-f, poikilitic garnet with quartz and carbonate inclusions clearly shows a compositional zoning that varies as a function of the nature of the included mineralogy: garnet around carbonate inclusions is dark grey and has lower Mn content, whereas garnet around quartz inclusions is light grey because of higher Mn content. Fig. 7g-h show similar zoning in skeletal garnet: when garnet is in contact with Stage\#2 clinopyroxene it has lower Mn and higher Ca and Fe. Bright garnet is preserved far from the inclusions (Fig. $7 \mathrm{~g}$ ). Lawsonite is found as either large $(100-500 \mu \mathrm{m}$, Lws1), locally inclusion-rich prophyroclasts (with inclusions of mainly quartz, titanite, rutile and carbonaceaous material) or smaller $(<50 \mu \mathrm{m}$ in size), inclusion-free euhedral crystals (Lws2). In some samples, clinopyroxene is not present and the dominant silicate phase is green amphibole. Pumpellyite locally replaces Lws1, either rimming or totally replacing the lawsonite porphyroclasts, and is interpreted as a late stage retrograde phase (sample cor13-28c, Table S2). All together, the microstructural relationships suggest that the Stage\# 1 paragenesis clinopyroxene1 (Cpx1) + lawsonite1 (Lws1) is replaced by the Stage\#2 paragenesis composed by carbonate + clinopyroxene 2 (Cpx2) \pm garnet \pm lawsonite2 (Lws2) \pm blue amphibole.

Metasomatic rocks from the Punta Favalta outcrop (sample 1cor146a) display some remarkable features compared to other samples in the same structural position. The rock is characterized by a banded structure with domains of quartz + blue amphibole + hematite + deerite, and domains of carbonate + clinopyroxene + garnet + hematite + deerite with relicts of blue amphibole and epidote (Fig. 5e). A detailed description of this sample is beyond the aim of this paper, however, key observations about carbonation deserve to be pointed out. In carbonate-rich domains, blue amphibole is only locally found as a relict phase being replaced by clinopyroxene and, locally, epidote is pseudomorphically replaced by garnet or rimmed by clinopyroxene (Fig. 6f). Ca-carbonate is in textural equilibrium with clinopyroxene, garnet, but also hematite and deerite (Figs. $6 \mathrm{f}$ and S1). Fresh aragonite was found as inclusion in hematite suggesting that carbonation took place at oxidized conditions. Deerite is quite abundant and occurs as inclusions in both quartz (together with hematite) and calcite. It is worth noting that the assemblage quartz + deerite + hematite has been widely reported in quartzite and metacherts from many localities of Alpine Corsica (Vernié et al., 1986). The microstructural relationships in carbonate-rich layers suggest that epidote and blue amphibole are destabilized to form the peak paragenenesis composed of aragonite + clinopyroxene + garnet + hematite + quartz + deerite (Fig. 6f).

\subsubsection{Serpentinite-continental crust}

Samples of Stage\#1 and Stage\#2 metasomatic rocks were collected in the Monte Muffraje area (Fig. 2a). Carbonated metasomatic rocks forming at the expense of Stage\#1 rocks display mm-banded fabric defined by the alternation of carbonate-rich and silicate-rich domains, the latter ones forming either continuous layers or isolated patches with thicknesses ranging from $50 \mu \mathrm{m}$ to $5 \mathrm{~mm}$ (Fig. 4 in Piccoli et al., 2016). Silicate layers are mainly composed of Stage\#1 clinopyroxene \pm lawsonite (Lws1) \pm quartz. Grain size ranges from $\mu \mathrm{m}$ to $\mathrm{mm}$. Carbonate (calcite after aragonite) displays prismatic habit, with elongation axes oriented at a high angle to the main rock fabric, and it grew either with crack-seal texture or as pods within silicate-rich domains resulting in corrosion-like textures. Two clinopyroxene generations can be recognized by their different color in plane-polarized light and on the basis of microstructural evidence. The first generation (Cpx1), characteristic of Stage\#1 metasomatism, comprises acicular crystals forming mm-sized fan-shape aggregates. Cpx1 aggregates typically have embayed margins filled by carbonate. Remnants of single clinopyroxene fibers occur within the carbonate crystals (Fig. 7b). The crystallographic orientation of these remnants relative to the larger aggregates indicates that they formerly belonged to a single crystal. A second generation of clinopyroxene (Cpx2), characteristic of Stage\#2 metasomatism, crystallized around Cpx1 (Fig. 7b) and is also present as isolated crystals in the carbonate domains. Lawsonite (Lws1) in metasomatic carbonated metasomatic rocks is found as large, inclusion-rich crystals (with dominant quartz, titanite, and rutile inclusions), whereas lawsonite in veins is inclusion free (Lws2, see also Section 5.2.4). Garnet is present in both carbonate and silicate-rich domains with euhedral to sub-euhedral habit. Poikiloblastic garnet includes mainly quartz, titanite, carbonate (calcite/aragonite) and lawsonite. Garnet also forms veins and pods together with carbonate. When present, quartz is granoblastic and is found as lens-shaped domains or rimming clinopyroxene aggregates together with garnet. Quartz can be either coeval with respect to carbonate and garnet (suggested by quartz rimming clinopyroxene together with garnet) or related to the retrograde evolution. Phengite is found as a late stage product crystallizing in fractures parallel to the rock foliation. Altogether, the microstructural relations suggest that a first paragenesis Cpx1 + Lws 1 is replaced by a second paragenesis: aragonite $+\mathrm{Cpx} 2+$ garnet \pm quartz.

The metasomatic overprint in this outcrop is pervasive, and the definition of a protolith rock is not obvious. Nevertheless, two samples preserve features suggesting that this metasomatic halo formed at the expense of continental basement rocks. Sample 1 cor14-10d, collected within the metasomatic rind, appears unaffected by the typical patterns of Stage\#1 or Stage\#2 metasomatism, and is composed of blue amphibole, phengite, lawsonite and garnet. In this sample, garnet preserves a Mg-Fe core typical of the pre-Alpine HT paragneiss forming the continental basement slices (Martin et al., 2011), and is overgrown by a higher $\mathrm{Ca}-\mathrm{Fe}$ component representative of the Alpine metamorphism (Fig. 6g; Table S2).

Sample 1 cor14-10 g likely escaped Stage\#1 metasomatism, but displays considerable evidence for Stage\#2 carbonate metasomatism. The rock has a prophyroclastic fabric defined by jadeite porphyroclasts wrapped by a foliated matrix mainly consisting of Ca-carbonate, phengite, and quartz (Fig. 5f). The jadeite clasts range from 100 to 500 $\mu \mathrm{m}$ in size. Some portions of the jadeite crystals contain tiny ameboidal quartz inclusions (Fig. 7c). This kind of microstructure is commonly described in jadeite-bearing rocks formed by metamorphic conversion of former albite following the prograde reaction albite $=$ jadeite + quartz (Compagnoni et al., 2012), and also occurs in the jadeite-bearing orthgneiss of the studied unit. The jadeite clasts are partially replaced by Ca-carbonate and late phengite, crystallizing along fractures (Fig. 7c,d), following the same microstructural patterns of carbonation observed for diopside in Stage\#1 rocks (Fig. 5a in Piccoli et al., 2016). Ca-carbonate is the main constituent of the matrix, found as coarsegrained granoblasts. Granoblastic quartz forms lens-shaped domains. Late albite rims the margins of jadeite clasts and jadeite remnants in the carbonate matrix together with phengite. The presence of jadeitebearing orthogneiss in the same area (west of Punta Caldane; Vitale Brovarone et al., 2011a) and the recognition of former pre-Alpine paragneiss in the metasomatic rind (this study), lead us to propose that this sample originally was a granitic or leucocratic igneous rock, belonging to a slice of pre-Alpine continental basement, and successively carbonated during the HP fluid-rock interactions (see Section 8). These observations suggest that in the Monte Muffraje area, the lower part of the metasomatic rind develops at the expense of a slice of preAlpine continental basement. This continental slice is probably the lateral termination of the thicker continental sliver that crops out to the south, in the area of Punta di Caldane.

\subsubsection{Continental crust-Mesozoic metasediments}

The first few meters of the metasediments overlying the continental crust consist of a chaotic sequence of carbonated mafic/ultramafic rocks. 

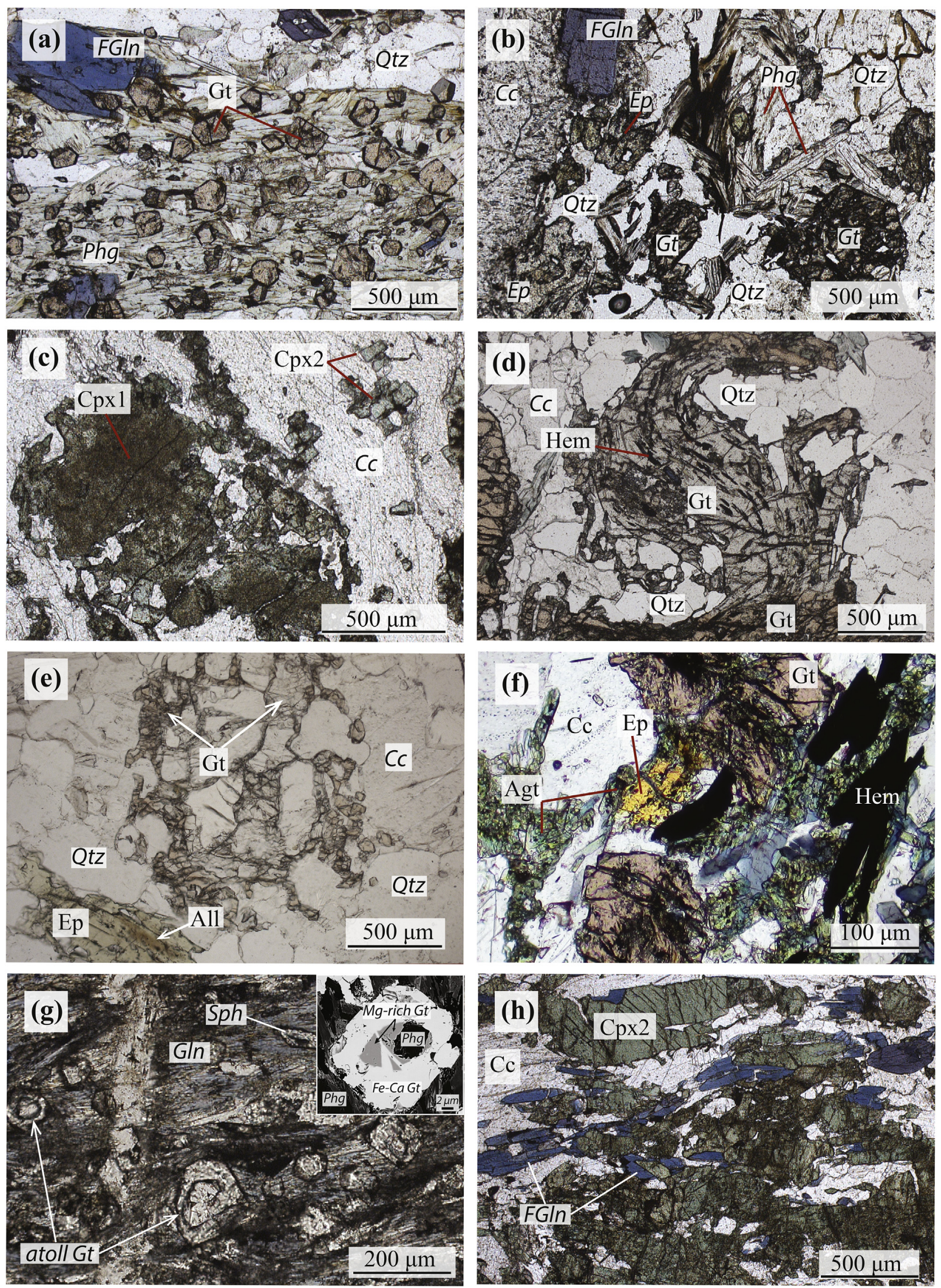
In thin section, amphibole + chlorite cm-nodules embedded in a carbonate-rich layer display a continuous foliation marked by chlorite and green amphibole, whereas carbonate is interstitial. When present, clinopyroxene forms either small stubby neoblasts with deep green pleochroism or, more rarely, larger porphyroblasts with sharp optical zoning comprising brownish cores and deep green pleochroic rims (Fig. $5 \mathrm{c}$ in Piccoli et al., 2016). Green pleochroic clinopyroxene is also present as inclusions in amphibole crystals together with calcite. Therefore, two generations of clinopyroxene are distinguished: $\mathrm{Cpx} 1$ porphyroblast cores and Cpx2 rimming Cpx1 or forming smaller neoblasts. Based on the microstructural relationships, only Cpx2 is considered in equilibrium with the paragenesis green amphibole + chlorite + carbonate. Blue amphibole, garnet and phengite may also be present in some samples.

Carbonate-quartz-rich rocks are also present within the carbonated mafic/ultramafic sequence. These rocks display mm-banded fabric of alternating carbonate-rich and silicate-rich domains (quartz, clinopyroxenes and blue amphibole, Fig. 3c3). A continuous schistosity (Passchier and Trouw, 2005) is marked by phengite, clinopyroxene, blue amphibole, and epidote preferred orientation. Grain size ranges from $\mu \mathrm{m}$ to $\mathrm{mm}$. Clinopyroxene is found in sub-euhedral prismatic crystals, with deep green pleochroism. No optical zoning is observed in the clinopyroxene (Fig. 6h). Garnet is present in mm-sized crystals, colorless in thin section. Some samples display weakly zoned, inclusion-rich garnet (pink core and colorless rim) with dominant quartz, calcite/aragonite, phengite, and zircon inclusions. More retrogressed samples display idioblastic crystals of blue amphibole ( $\mathrm{mm}$ in size), with a lavender-blue pleochroism. Phengite wraps around garnet porphyroblasts. Epidote is present in prismatic, colorless crystals, except for local brown allanitic cores. Lawsonite pseudomorphs may also be present. Tourmaline is an accessory mineral. Considering the more homogeneous mineralogy and the microstructural evidence, we propose that only one equilibrium paragenesis is present: carbonate + garnet + phengite \pm clinopyroxene \pm blue amphibole.

\subsubsection{Vein material}

Several types of veins are found in association with the carbonated metasomatic systems studied herein. In all vein types, the carbonate phase is always compositionally pure Ca-carbonate with a rod-shaped habit orientated at a high angle to the vein wall. The vein crack-seal texture suggests that the veining event is linked to fluid-overpressure and hydrofracturing (Ramsay, 1980). This is consistent with the observation of hydraulic breccias within the metasomatic rind and suggests brittle deformation during the fluid-rock interactions at HP conditions (Piccoli et al., 2016).

5.2.4.1. Carbonate veins. This kind of vein is characterized by elongated carbonate crystals and small clasts of wallrock inclusions aligned parallel to the vein wall (Fig. 8a), features typical of crack-seal (Ramsay, 1980). No vein selvage is observed in the wallrock. This kind of vein is found within the metasomatic rind along the serpentinite-Mesozoic metasediments contact and along the continental crust-metasediments contact (see Section 5.2.3).

5.2.4.2. Carbonate + omphacite veins. These are elongate, blocky veins (Oliver and Bons, 2001) with smaller omphacite crystals seeded on the wallrock and outgrown by larger elongate calcite crystals (Figs. 3b3 and $8 \mathrm{~b})$. The observation of the growth competition indicates that crystals grew into a fluid-filled crack, with a crack-seal mechanism (Oliver and Bons, 2001 and references therein). This kind of vein displays a selvage in which the wallrock diopside has omphacite rims. The vein selvage is also characterized by the presence of phengite (Fig. 8b). However, microstructures do not establish if phengite was coeval to the carbonate precipitation in the vein. This kind of vein is found within the metasomatic halo along serpentinite-Mesozoic metasediments contacts.

5.2.4.3. Carbonate + Lawsonite \pm diopside. As in the carbonate + omphacite veins, calcite crystals are elongated and parallel to the vein wall (Fig. 3b4). Lawsonite is present as poikilitic prophyroblasts together with quartz, graphite, and rare titanite and calcite inclusions, or as small ( $\mu \mathrm{m}$ in size) inclusion-free crystals (Fig. 8c). Lawsonite is optically zoned with pinkish zones that correspond to high $\mathrm{Cr}$ content (Table S2; Fig. 8d). When present, clinopyroxene is found as small $(<100 \mu \mathrm{m})$ prismatic crystals overgrowing lawsonite crystals (Fig. 8c). This kind of vein has been observed within the metasomatic rind along the serpentiniteMesozoic metasediments and the serpentinite-continental crust contacts.

\section{Mineral chemistry}

\subsection{Clinopyroxene}

The compositional evolution of clinopyroxene displays common patterns in samples from different tectonostratigraphic positions. Fig. 9a shows jadeite-aegirine-QUAD ternary diagrams for clinopyroxenes in Stage\#1 rocks (unaffected by Stage\#2, sample 1cor12-11P) and Stage\#2 carbonated metasomatic rocks from the three types of tectonostratigraphic contacts (classification after Morimoto, 1989). In general, Stage\#1 clinopyroxene compositions (in both Stage\#1 rock unaffected by carbonate-metasomatism and relict Cpx1 in Stage\#2 rocks) plot in the QUAD field and are diopside ( $\mathrm{CaO} \sim 24 \mathrm{wt} \%, \mathrm{MgO} \sim 12 \mathrm{wt} \%$, $\mathrm{FeO} \sim 8 \mathrm{wt} \%)$. Most Stage\#2 zoned clinopyroxene crystals (Cpx2) from samples overlying serpentinites have $\mathrm{Na}-\mathrm{Al}$ enrichment with respect to the core (Cpx1), and omphacitic compositions. However, some samples have $\mathrm{Na}-\mathrm{Fe}^{3+}$ enrichment in the rim, and plot in the aegirine-augite field. Clinopyroxene in carbonate veins is omphacite, whereas in carbonate + lawsonite veins it is diopside. Clinopyroxene in carbonated metasomatic rocks formed at the expense of metasediments has high Mn content (up to $\sim 2-3 \mathrm{wt} \%$, Table S2). Mn may be present in the core as well as in the newly crystallized omphacite (Fig. 7a and h, respectively). Chromium in clinopyroxene occurs in significant amounts only in two samples: cor13-21d and 1 cor14-6a. In sample cor13-21d, Cpx1 is an Al-rich diopside with higher $\mathrm{Cr}$ content ( 1 wt\%, Table S2) than $\mathrm{Cpx} 2$ in the $\operatorname{rim}(\sim 0.6 \%)$. The plausible ultramafic origin of this sample has been discussed in Piccoli et al. (2016) based on bulk-rock trace element analysis. In sample 1cor14-6a, clinopyroxene is zoned; $\mathrm{Cr}$ rich domains have as much as $\sim 1 \mathrm{wt} \% \mathrm{Cr}_{2} \mathrm{O}_{3}$.

\subsection{Garnet}

Fig. 9b reports the garnet composition for the carbonated metasomatic rocks in a grossular-almandine-spessartine ternary diagram; the pyrope content is always very low ( $\mathrm{X}_{\mathrm{Mg}}$ ranging from $\sim 0$ to 0.03 ) and

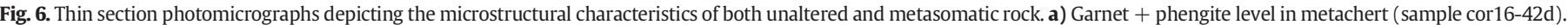

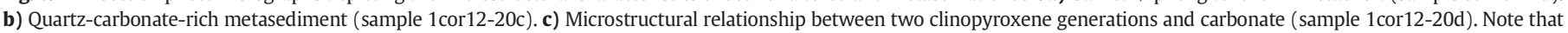

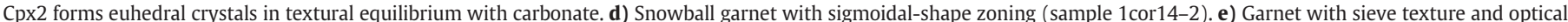

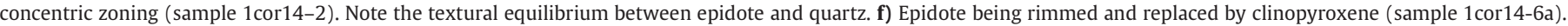

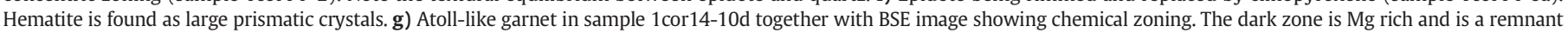
of pre-Alpine HT metamorphism. (see also Martin et al., 2011) h) Clinopyroxene and ferroglaucophane in metasomatic marble overlying the continental crust (sample cor13-21b). 

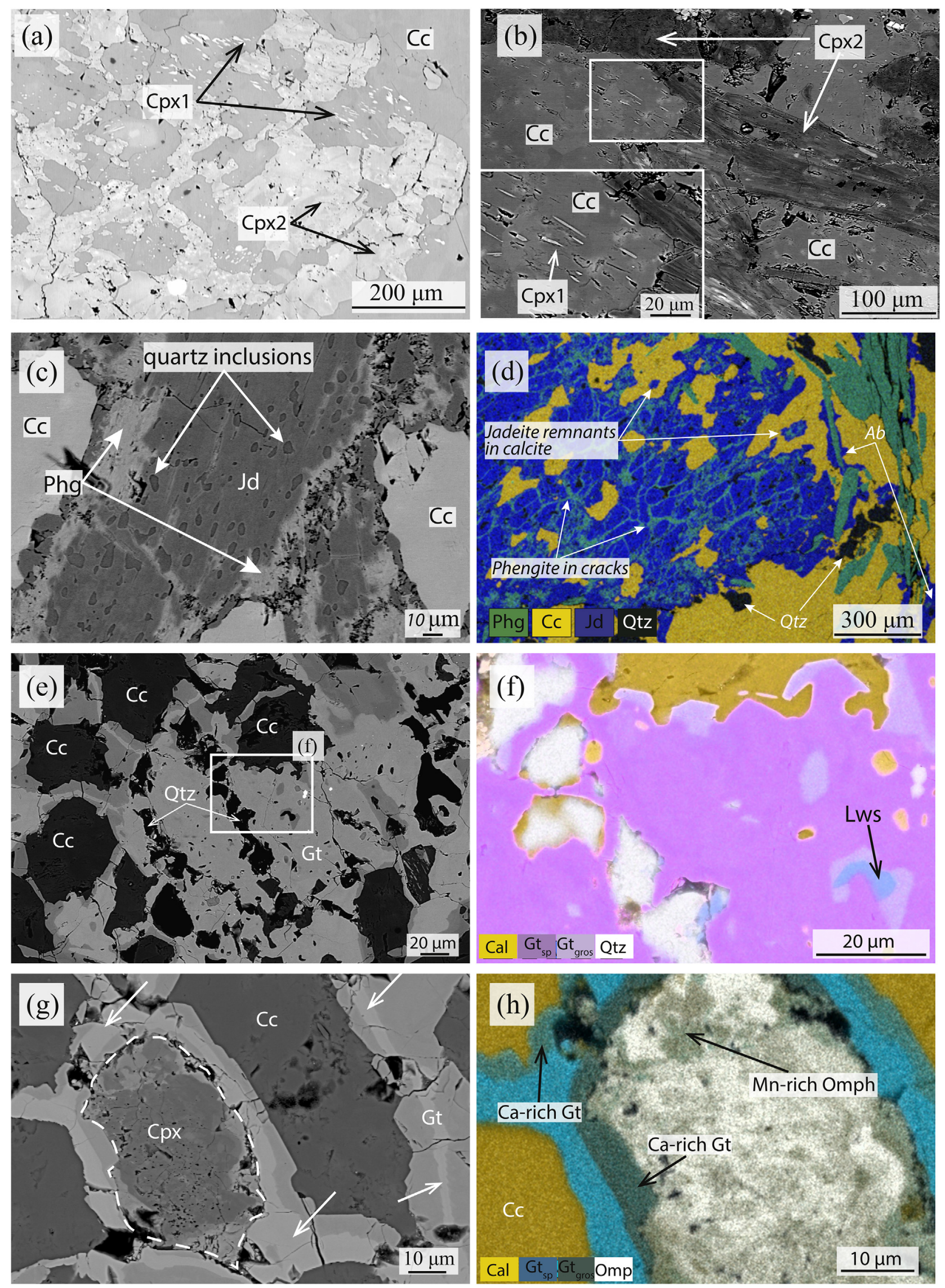

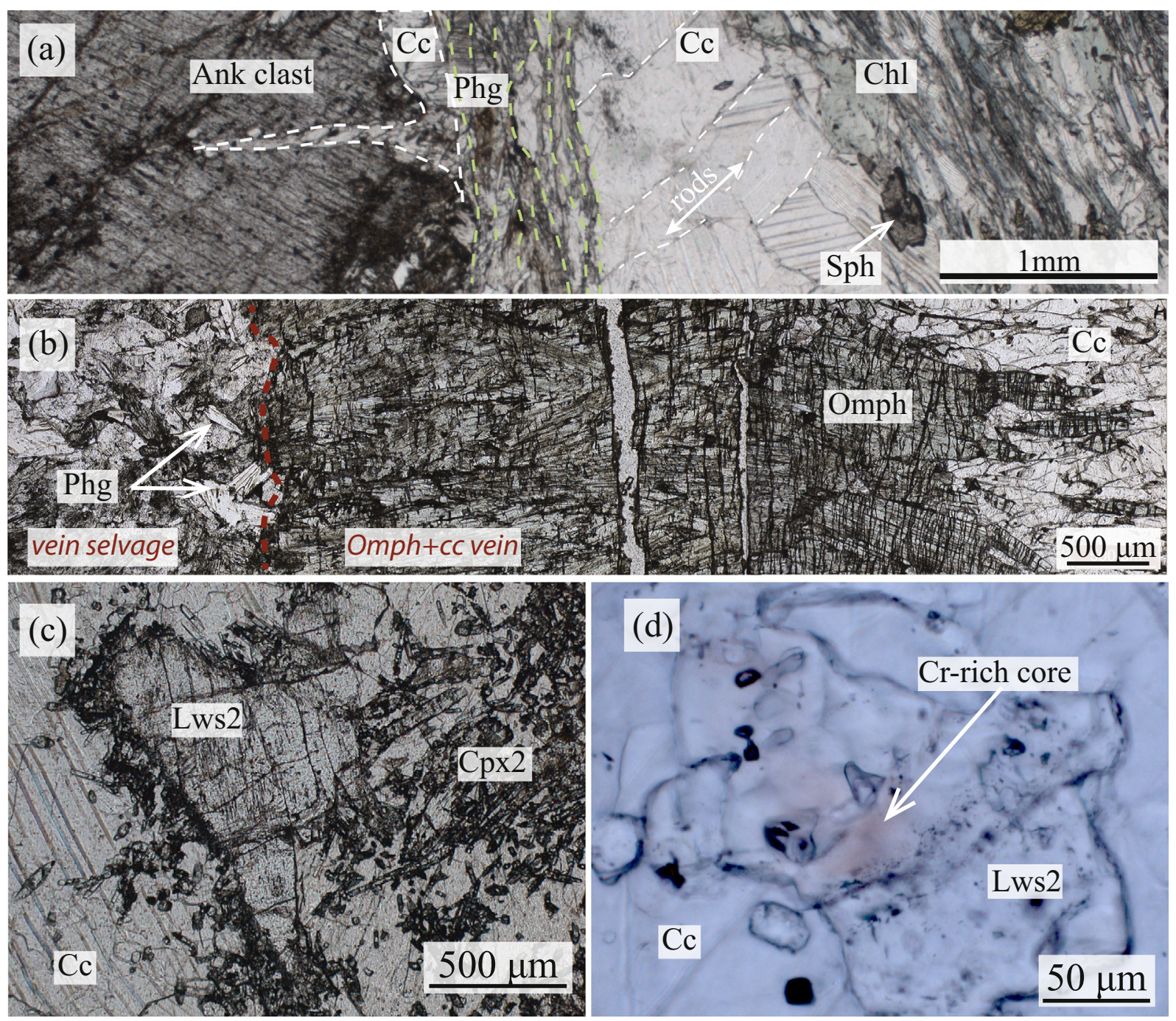

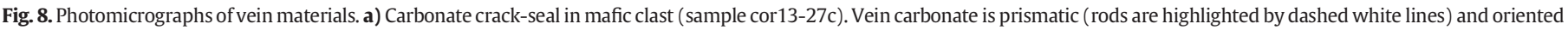

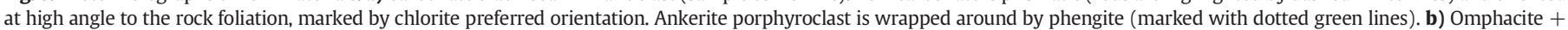

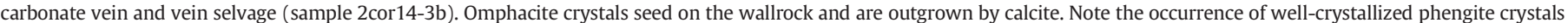

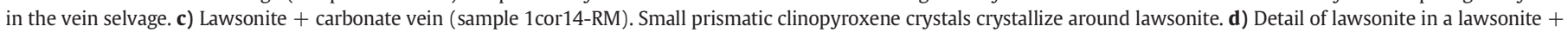

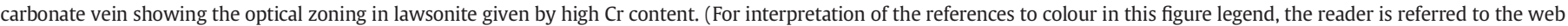
version of this article.)

the andradite component is large only in garnet cores from sample 1 cor14-6a and in garnet from sample 1 cor14-12b (Table S2). Garnet in samples along the serpentinite/metasediment contact is zoned. In most cases, garnet zoning corresponds to an increase in Ca-Fe relative to $\mathrm{Mn}$ (Fig. 10a,b). In some cases, (Fig. 10c,d) the rim has a sharp enrichment in the spessartine component (with $\mathrm{X}_{\mathrm{Sps}}$ rising from 21 to $43 \%$, $\mathrm{X}_{\mathrm{Alm}}$ decreasing from $\sim 53$ to $\sim 34 \%$, and $\mathrm{X}_{\mathrm{Grs}}$ remaining stable, see also sample 1cor12-20d in Table S2). Fig. 10d also shows an electron microprobe map of garnet from sample 1cor12-20d: together with the increase in $\mathrm{MnO}$, the garnet rim also displays oscillatory zoning in $\mathrm{Cr}_{2} \mathrm{O}_{3}\left(\mathrm{Cr}_{2} \mathrm{O}_{3}\right.$ up to $\sim 0.15 \mathrm{wt} \%)$. In this same sample, smaller, euhedral crystals have a more homogeneous composition ( $\mathrm{X}_{\mathrm{Alm}} \sim 25 \%, \mathrm{X}_{\mathrm{Sps}} \sim 36 \%, \mathrm{X}_{\mathrm{Grs}} \sim 39 \%$ ). Garnet in sample 1cor14-12b displays complex compositional zonation. Mn rich garnet preserved around quartz inclusions has an average

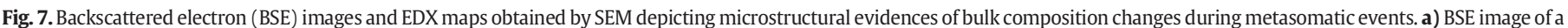

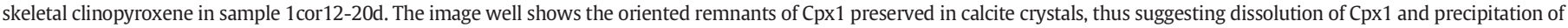

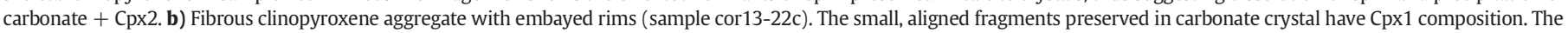

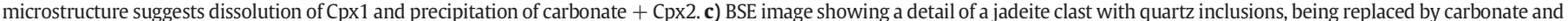

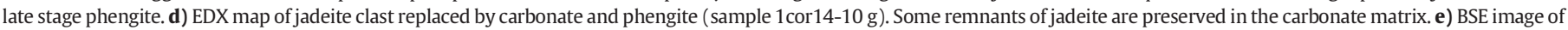

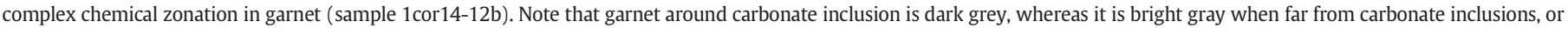

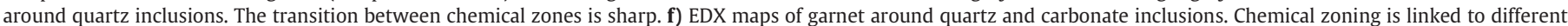

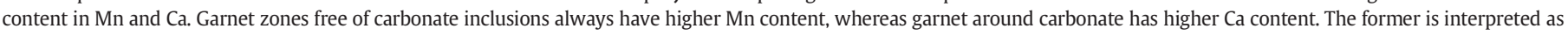

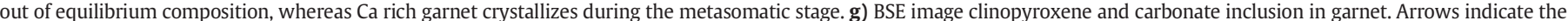

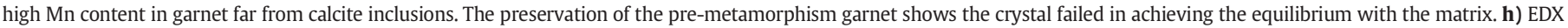

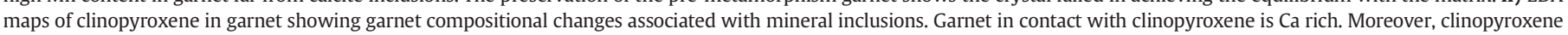
has high Mn content suggesting that Mn is exchanged between garnet and clinopyroxene. 
(a) Serpentinite-gneiss Serpentinite-metasediments
O 1 cor12-11P
1 cor14-12b Cpx1
$\diamond 1 \operatorname{cor} 14-12 \mathrm{~b} \mathrm{Cpx} 2$
$\diamond 1 \operatorname{cor} 12-20 \mathrm{~d}$
cor13-22c Cpx1
$\diamond \operatorname{cor} 13-22 \mathrm{c} \mathrm{Cpx} 2$
1 cor14-10g
$\diamond 1$ cor14-6a
Veins
$+1 \operatorname{cor} 12-11 \mathrm{~N}$
OF3597

60

70 Omphacite

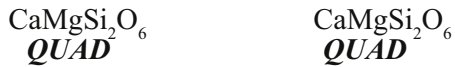

$$
\text { QUAD }
$$

QUAD

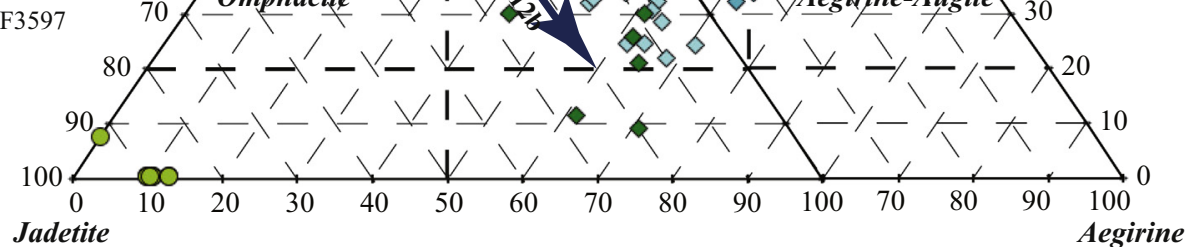

$\mathrm{NaAlSi}_{2} \mathrm{O}_{6}$

(b)

\section{Serpentinite-metasediments}

\begin{tabular}{|c|c|}
\hline 0 & 1 cor $12-20 d$ \\
\hline & cor13-28c \\
\hline & cor13-28a \\
\hline$\square \diamond 0$ & 1 cor $14-12 b$ \\
\hline$\square \diamond 0$ & 1 cor14-6a \\
\hline
\end{tabular}

(c)

\section{Almandine}

$\mathrm{NaFe}^{3+} \mathrm{Si}_{2} \mathrm{O}_{6}$

\section{Gneiss-metasediments}

cor13-21d Cpx1

$\checkmark$ cor13-21d Cpx2

$\diamond \operatorname{cor} 13-21 b$

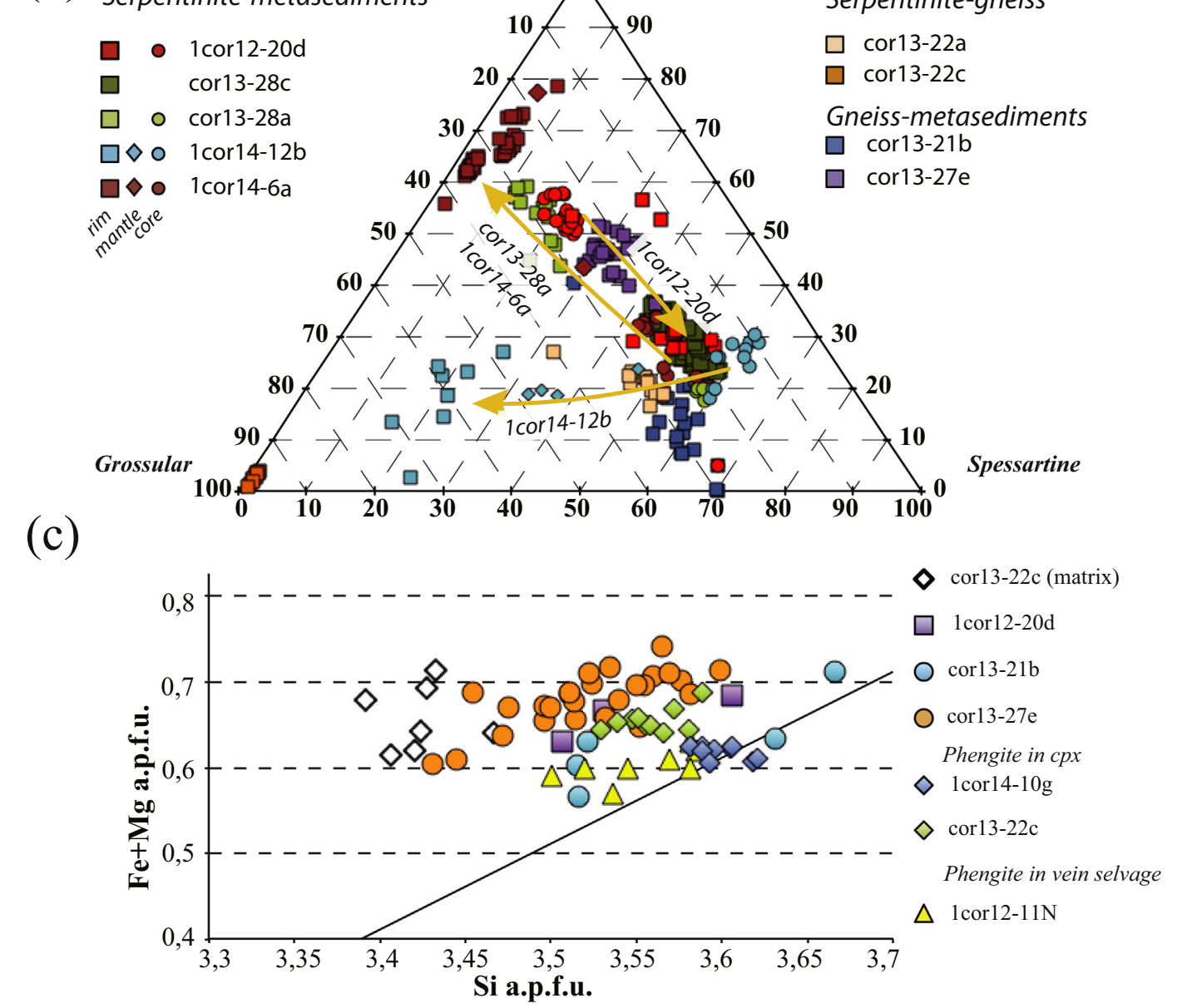

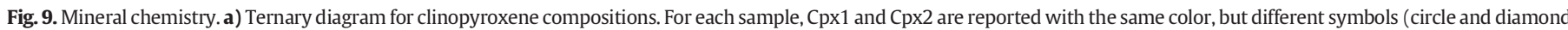

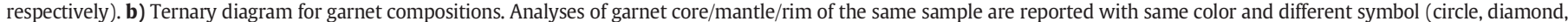

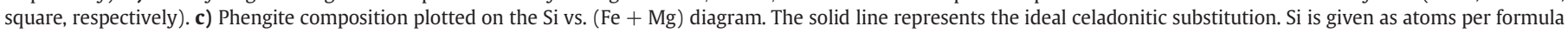
units (a.p.f.u.) on the basis of 11 oxygens.

composition of $\mathrm{X}_{\mathrm{Alm}} \sim 25 \%, \mathrm{X}_{\mathrm{Sps}} \sim 55 \%, \mathrm{X}_{\mathrm{Grs}} \sim 15 \%, \mathrm{X}_{\mathrm{Adr}} \sim 5 \%$, whereas Caricher garnet around calcite or clinopyroxene has an average composition of $\mathrm{X}_{\mathrm{Alm}} \sim 20 \%, \mathrm{X}_{\mathrm{Sps}} \sim 20 \%, \mathrm{X}_{\mathrm{Grs}} \sim 55 \%, \mathrm{X}_{\mathrm{Adr}} \sim 15 \%$. Matrix garnet in carbonated metasomatic rocks formed at the expense of continental basement rocks (samples cor13-22a and cor13-22c) has a Fe-Mn rich composition $\left(\mathrm{X}_{\mathrm{Alm}} \sim 20 \%, \mathrm{X}_{\mathrm{Sps}} \sim 49 \%, \mathrm{X}_{\mathrm{Grs}} \sim 31 \%\right.$ ), while anhedral crystals or garnet in veins is grossular rich $\left(\mathrm{X}_{\mathrm{Alm}} \sim 2.5 \%, \mathrm{X}_{\mathrm{Sps}} \sim 1 \%\right.$, $\mathrm{X}_{\mathrm{Grs}} \sim 96.5 \%$ ). Garnet in samples overlying continental basement 
(a)

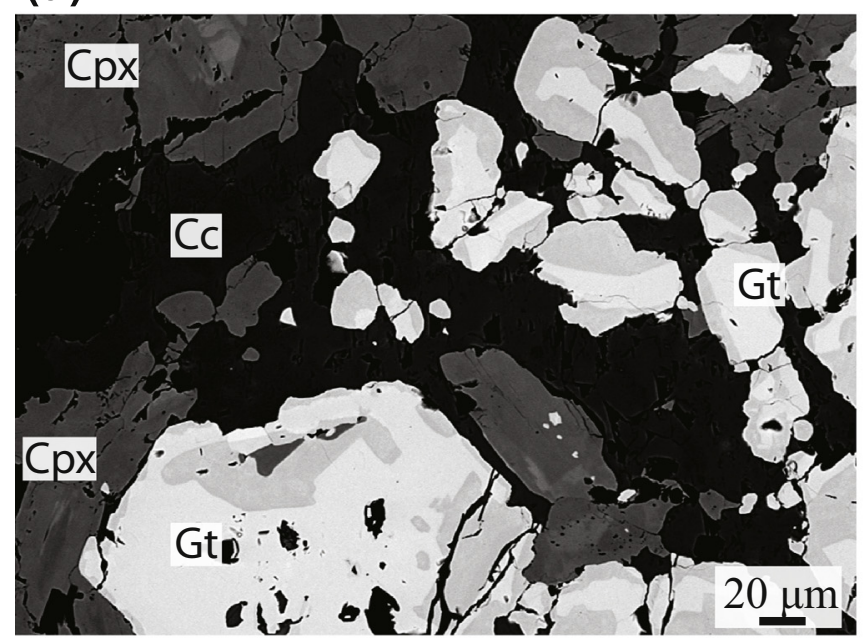

(c)

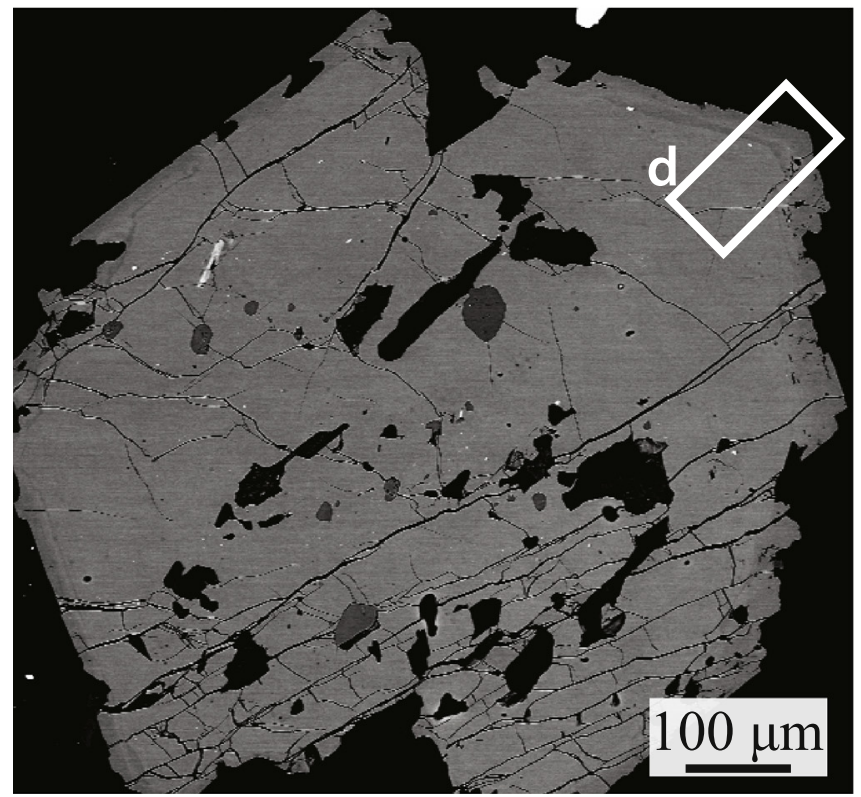

(b)

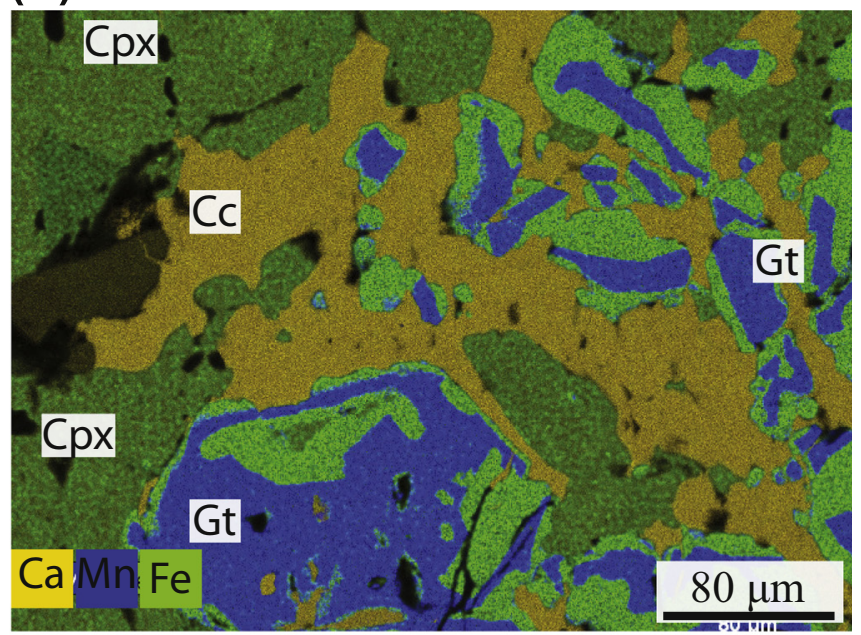

(d)
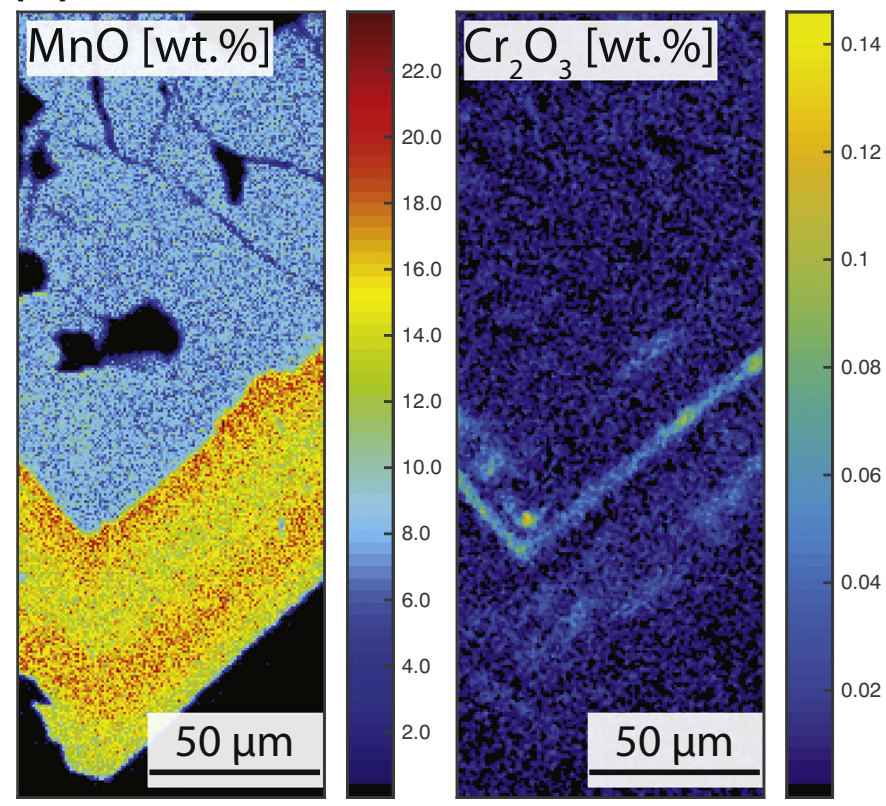

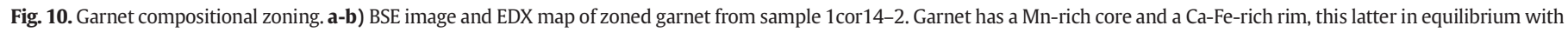

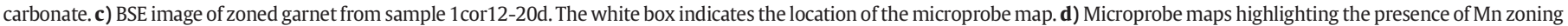
together with $\mathrm{Cr}$ oscillatory zoning in the rim (maps treatment with XMapTools software, Lanari et al., 2014).

(cor13-21b and cor13-27e) are unzoned with $\mathrm{X}_{\mathrm{Sps}}$ varying from one sample to another (Fig. 9b and Table S2).

\subsection{Phengite}

Potassium-rich white micas are phengites (Table S2), with Si content ranging between 3.5 and 3.6 atoms per formula unit (a.p.f.u.). All phengites have $\mathrm{K}$ around 1 a.p.f.u and quite homogenous $\mathrm{Fe}^{2+}$ and $\mathrm{Mg}$ contents ( $~ 0.1$ and $\sim 0.5$ a.p.f.u., respectively), with the exception of sample 1cor14-10 g which has lower Fe-Mg. Fig. 9c shows phengite compositions plotted on the $\mathrm{Si}$ vs. $\left(\mathrm{Fe}^{2+}+\mathrm{Mg}\right.$ ) (a.p.f.u.) diagram. Only phengite in samples cor13-21b and 1 cor14-10 g approach the ideal Tschermak substitution, whereas the other samples plot above the ideal substitution line. The high $\mathrm{Mg}$-Fe contents might result from a partial substitution of $\mathrm{Al}$ with $\mathrm{Fe}^{3+}$, quite common in $\mathrm{HP}$ terranes (Miyashiro and Shido, 1984). In sample cor13-22c, phengite crystals in the matrix have lower celadonite content than phengite replacing clinopyroxene, suggesting requilibration of the matrix crystals at a lower P condition.

\subsection{Amphibole}

Carbonated metasomatic rocks formed at the top of continental basement contain abundant sodic amphibole ranging in composition from glaucophane to ferroglaucophane (Fig. 11a). Green amphibole in the chaotic mafic/ultramafic sequence has tremolite composition (sample cor13-21d). Sodic amphibole in samples overlying the serpentinite basement has composition ranging from riebeckite to Mg-riebeckite, whereas green amphibole is actinolite (Fig. 11a,b, classification after Leake et al., 1997). Amphibole structural formula is calculated based on 23 oxygens and with $\mathrm{Fe}^{2+} / \mathrm{Fe}^{3+}$ estimation assuming 13 cations.

\subsection{Epidote}

Epidote composition is given using the ternary classification from Franz and Liebscher (2004). As Mn-bearing compositions are common, the ternary diagram was constructed with clinozoisite, epidote and 
(a)

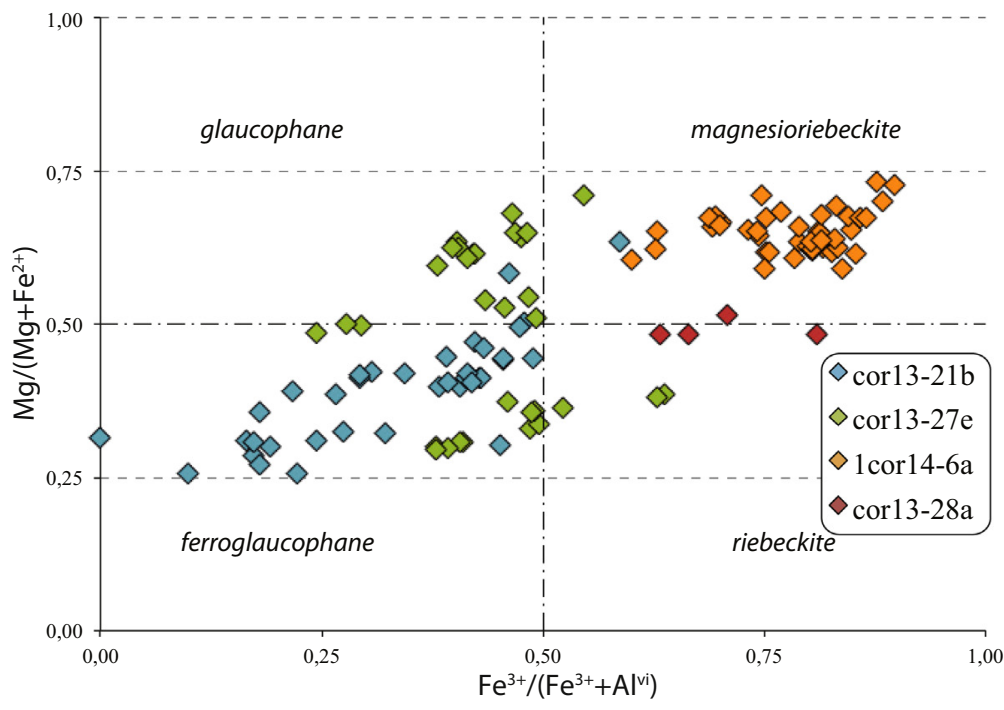

(b)

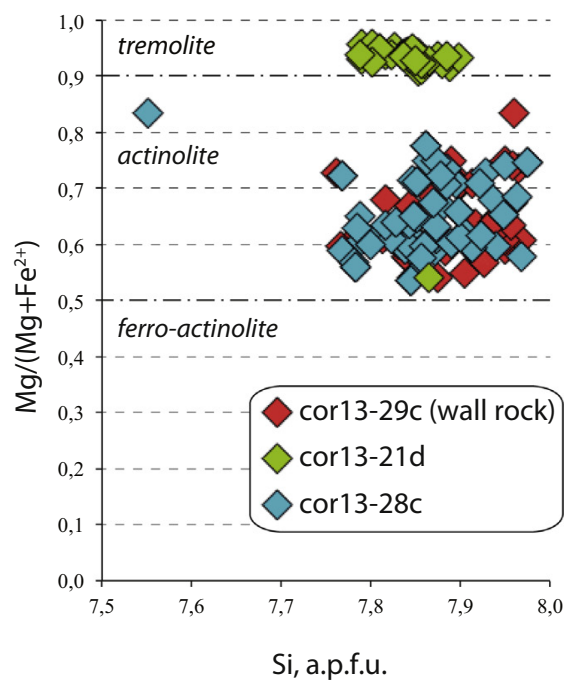

Fig. 11. Mineral chemistry. a) Classification diagram for sodic amphiboles; b) Classification diagram for calcic amphiboles. Classification after Leak et al. (1997).

piemontite endmembers. In sample 1 cor12-20d, epidote has high Mn and $\mathrm{Fe}\left(\mathrm{X}_{\mathrm{CZ}} \sim 0, \mathrm{X}_{\mathrm{Ep}} \sim 0.5\right.$ and $\mathrm{X}_{\mathrm{Pie}} \sim 0.5$; Table $\left.\mathrm{S} 2\right)$, but in other samples Mn-rich epidotes $\left(X_{\text {Pie }} \sim 0.7\right)$ and piemontite $\left(X_{\mathrm{Pie}} \sim 1\right)$ are found (samples cor13-28c and 1cor14-5). In sample cor13-27e, epidote is Fe rich but $\mathrm{Mn}$ poor $\left(\mathrm{X}_{\mathrm{Cz}} \sim 0.6, \mathrm{X}_{\mathrm{Ep}} \sim 0.4\right)$. Generally, epidote overgrowing lawsonite is related to retrograde evolution and has high clinozoisite content $\left(\mathrm{X}_{\mathrm{CZ}}\right.$ ranging from $\sim 0.7$ to $\sim 0.9$ ). In sample 1 cor14-6a, epidote has elevated $\mathrm{Cr}_{2} \mathrm{O}_{3}$ up to $2 \mathrm{wt} \%$.

\subsection{Lawsonite}

Lawsonite in carbonated metasomatic rocks is close to pure composition. In some carbonate + lawsonite veins, it is Ti-bearing $\left(\mathrm{TiO}_{2}\right.$ up to $\sim 1 \mathrm{wt} \%$, Table S2) and/or Cr-bearing $\left(\mathrm{Cr}_{2} \mathrm{O}_{3}\right.$ up to $3.25 \mathrm{wt} \%$, sample cor13-29, Table S2).

\subsection{Carbonate}

Carbonate is always nearly pure calcium carbonate, with the only exception being iron-rich carbonate nodules found in carbonated mafic/ultramafic lithologies together with actinolite-chlorite-rich assemblages.

\subsection{Deerite}

Deerite is present only in sample 1 cor14-6a. It departs significantly from end member composition and has considerable $\mathrm{MnO}$ ( $2.4 \mathrm{wt} \%), \mathrm{MgO}(\sim 2 \mathrm{wt} \%)$, and $\mathrm{TiO}_{2}(\sim 0.8 \mathrm{wt} \%)$, together with minor $\mathrm{Cr}_{2} \mathrm{O}_{3}(\sim 0.5 \mathrm{wt} \%)$ and $\mathrm{Al}_{2} \mathrm{O}_{3}(\sim 0.2 \mathrm{wt} \%)$.

\section{Discussion}

Lithological boundaries, together with fracture sets or permeable layers, are structural features that facilitate fluid channelization (e.g. Oliver, 1996; Oliver and Bons, 2001; Zack and John, 2007; Ague, 2014; Bebout and Penniston-Dorland, 2016). The multiple metasomatic products (Stage\#1 and Stage\#2) described in this study formed along the main lithological boundaries of the subducted section of oceanic/transitional lithosphere preserved in the lawsonite eclogite-facies, i.e. the basal unconformity separating Mesozoic sediments from the underlying rocks. Consequently, these interfaces acted as major fluid conduits for a protracted period of time, from prograde to peak conditions and probably during early stages of exhumation as well. Field, microstructural and geochemical data (Piccoli et al., 2016; this study) strongly indicate that carbonate minerals (mainly Ca-carbonate) were involved in these protracted fluid-mediated processes, including possible carbonate dissolution/decarbonation during Stage\#1, and strong reactivity between the silicate minerals and carbon-bearing fluids during Stage\#2. These processes did not take place in-situ in closed systems (e.g., dissolutionprecipitation; Ferrando et al., 2017), but was mediated though largescale reactive fluid flow involving transient carbon mobilization and successive carbonation of initially carbon-free lithologies. The high lithological variability of the metasomatized suites provides a good means to assess: (i) the reactivity of different rock types to deep carbon-bearing fluids and rock carbonation; (ii) the fluid composition; and (iii) the fluid sources and the possible scale of the reactive fluid flow. These three points will be discussed below.

\subsection{Protolith rocks}

\subsubsection{Evidence for extreme transformation of Mn-metacherts}

In the field, incomplete metasomatic transformation and preservation of partially replaced Mn-metacherts is only locally found (Fig. 3a4) and characterized by the progressive overgrowth of primary Mn-rich garnet by metasomatic Ca-rich garnet. Similar trends are also observed in carbonated metasomatic rocks for which a protolith is difficult to identify in the field. Mn-rich garnet in some carbonated metasomatic rocks is found either in the core, rimmed by Ca-rich garnet, or as patchy compositional zones controlled by local equilibria between relict (e.g. quartz) and metasomatic (e.g. carbonate) phases (see Figs. 7f,g,h and 10a,b). Even in the latter case, microstructural relationships indicate that the Mn-rich garnet was the stable garnet prior to metasomatism. The local occurrence of annuli of high Mn near the rim may result from garnet resorption (Kohn and Spear, 2000). Alternatively, external fluid infiltration may add Mn to the system, or enhance the breakdown of Mn-rich phases such as epidote and the internal redistribution of $\mathrm{Mn}$ in the rock (piemontite or Mn-bearing epidote is very common in Alpine metacherts, e.g. sample 1cor14-5c; Yang and Rivers, 2001). The observed epidote breakdown reaction in sample 1 cor14-6a, and the presence of Mn-rich epidote ( $\mathrm{MnO}$ up to $22 \mathrm{wt} \%$ ) 
in some of the carbonated metasomatic samples (e.g. sample 1cor1220d; cor13-28c) support the hypothesis of redistribution of Mn inside the rock during fluid infiltration. Moreover, in some cases the Mn enrichment in the garnet rim is associated with Cr-oscillatory zoning. Chromium zoning cannot be explained by the breakdown of an internal source (i.e., Cr-bearing phases are absent). Instead, it requires the infiltration of an external fluid, likely derived from mafic/ultramafic rocks. All together, these features indicate that Mn-rich garnet can be used as a marker for metasomatized metacherts by both preservation of relict Mn-rich garnet cores, or by fluid-mediated redistribution of Mn in the rock and growth of Mn-rich garnet rims.

An additional marker for carbonation of metacherts may be the presence of deerite-bearing assemblages, which are usually described in carbonate-free, metamorphosed metacherts from Alpine Corsica (Vernié et al., 1986) as well as other blueschist-facies (Franciscan, Alps, Turkey, the Aegean, and New Caledonia; Muir Wood, 1979) and eclogite-facies terrains (Tianshan, Zhang et al., 2017). We propose that deerite and hematite observed in sample 1 cor14-6a are inherited from the protolith and indicate that, in Punta Favalta, Mn-rich metacherts were carbonated during subduction metasomatism.

\subsubsection{Evidence for extreme transformation of mafic and felsic pre-Alpine basement}

Two key observations allow identification of the pre-Alpine continental basement rocks as a protolith for some extremely metasomatized rocks. Martin et al. $(2011,2014)$ showed the preservation of preAlpine, Mg-Fe-rich HT garnet in Stage\#1 metasomatic rocks is a marker of replacement of former (carbonate free) mafic paragneiss. In carbonated metasomatic rocks, no evidence for the preservation of pre-Alpine HT garnet was found. Nevertheless, this relict garnet was found in a lens of mafic schists within the metasomatic rind of Mt. Muffraje, which escaped both Stage\#1 and Stage\#2 metasomatism (1cor14-10d, Fig. $6 \mathrm{~g}$ ). Secondly, from the same outcrop, extremely carbonated rocks (sample 1cor14-10 g) contain relicts of jadeite porphyroblasts that likely formed by prograde transformation of large albite crystals, as observed in orthogneiss unaffected by metasomatism in the San Petrone continental basement slices. This observation suggests that the continental crust slice in this area also contained jadeite-bearing orthogneiss. Alternatively, the presence of albitic feldspar later converted to jadeite in carbonatebearing rocks may be explained by an arkosic detrital component in the original sediment. Silicoclastic metasediments are found throughout the HP units of Alpine Corsica, known as the San Pietro di Tenda metasedimentary formation, where arkosic layers within basaltic lavas have been reported (e.g., Caron and Delcey, 1979; Caron et al., 1981; Péquignot et al., 1984; Lahondère, 1996). However, even if the origin of the rock remains unclear (metagranite or metaarkose), the microstructures show jadeite being replaced by carbonate (Fig. 7d), thus supporting the high reactivity, at HP conditions, between carbon-bearing fluids and clinopyroxene.

The above evidence documents that in this area, HP fluid-mediated carbonation affected both mafic paragneiss and felsic orthogneiss belonging to a continental basement slice. Notably, the jadeite-bearing sample indicates that carbonation also occurred without a precursor Stage\#1 diopside-lawsonite metasomatic stage, and represents the first evidence for carbonation of metafelsic rocks during HP-LT metasomatism. Thus, HP carbonation by infiltration of carbon-bearing aqueous fluids may be an important process for deep carbon sequestration in continental subduction and collisional settings.

\subsubsection{Evidence for metasomatism and carbonation of ultramafic rocks}

The serpentinite basement of the San Petrone unit does not show significant metasomatic overprinting or evidence for carbon-bearing fluid infiltration, such as carbonate, talc, and amphibole crystallization. This suggests that either this lithology was not reactive, or fluids did not infiltrate it.
In the Punta Ventosa and Punta Caldane areas, chaotic sequences of mafic/ultramafic material embedded in carbonate matrix overlie the continental crust sliver and show evidence for HP metasomatism. The mineral assemblage (chlorite, actinolite, and minor clinopyroxene and ankerite) and whole rock geochemical signature of these rocks (Piccoli et al., 2016) demonstrate their mafic/ultramafic origin. Sedimentary breccias containing ultramafic/mafic clasts are commonly described in active slow-spreading ocean basins and their metamorphic equivalents (Lagabrielle and Cannat, 1990; Lagabrielle et al., 2015), and are the likely protolith for these chaotic sequences. The metasomatism of metasedimentary breccia containing serpentinite clasts transformed into carbonate + chlorite + actinolite assemblages could potentially be caused by an increase in $\mathrm{X}_{\mathrm{CO} 2}$ during infiltration of external carbonbearing fluids, as suggested by abundant carbonate veins, crack-seals, and hydraulic breccias (Figs. 4f, 8a).

The above evidence clearly shows that mafic/ultramafic rocks can be extremely reactive with carbon-bearing fluids at HP conditions, yet the serpentinite basement is uncarbonated. This lack of carbonation might be linked to the fluid chemistry or to low permeability to fluid infiltration. In the first hypothesis, the $\mathrm{X}_{\mathrm{CO} 2}$ of the fluid $\left(\mathrm{X}_{\mathrm{CO} 2}=\mathrm{CO}_{2} /\left(\mathrm{H}_{2} \mathrm{O}+\mathrm{CO}_{2}\right)\right.$ could have been too low to destabilize the antigorite. Considering the observed co-stability of lawsonite and aragonite in Stage\#2 rocks, the reaction lawsonite + aragonite + quartz $=$ grossular sets a lower limit of $\mathrm{X}_{\mathrm{CO} 2}$ at 0.00125 for the fluid in equilibrium with these rocks (Fig. S2a; see Supplementary material for modeling conditions). For this value of $\mathrm{X}_{\mathrm{CO} 2}$, antigorite in the underlying serpentinite should be destabilized $\left(\mathrm{X}_{\mathrm{CO} 2}<0.001\right.$ in Fig. S2a), whereas diopside in the Stage\#1 rocks should be stable $\left(\mathrm{X}_{\mathrm{CO} 2}<0.004\right.$, Fig. S2). This observation, together with the local carbonation of ultramafic material within the sedimentary pile, suggests that the asymmetry of the metasomatic rinds was most likely due to permeability contrasts along lithological boundaries rather than fluid chemistry. Actually, the existence of permeability contrasts between two adjacent lithologies has the effect of diverting the fluid flow toward higher permeability region, leading to asymmetrical distribution of reaction progress (Breeding et al., 2003; Ague, 2007). Consequently, we propose that large gradients in fluid fluxes, resulting from permeability contrasts between litho-tectonic rock packages, were responsible for the formation of strongly asymmetric metasomatic front. These permeability contrasts also probably controlled fluid flow channelization at the regional scale along at least $10-12 \mathrm{~km}$ of subducted transitional lithosphere exposed in the San Petrone unit (See Section 7.3 for further discussion).

\subsection{Fluid composition and sources}

The carbonated metasomatic rocks display a complex geochemical signature that suggests a multi-source nature for the metasomatic fluids, by analogy to what has been proposed by previous studies on Stage\#1 metasomatic rocks (Martin et al., 2011; Vitale Brovarone et al., 2014b).

The most striking geochemical features of Stage\#2 are enrichments in $\mathrm{Ca}, \mathrm{C}$ (Ca-carbonate), $\mathrm{Na}$ (Na-clinopyroxene), and $\mathrm{Cr}$ (oscillatory zoning in garnet, lawsonite, and clinopyroxene; $\mathrm{Cr}$-rich lawsonite in veins). Ca enrichment during carbonation happens via carbonate precipitation and silicate replacement, thus implying a combined supply of Ca and C. Processes of carbonate dissolution in aqueous fluids are expected to release fluids with 1:1 M Ca:CO $\mathrm{CO}_{2}$ ratios (Ague and Nicolescu, 2014) that would easily explain the reprecipitation of Ca-carbonate rich assemblages (Piccoli et al., 2016; this study). Carbonate-rich rocks, such as metasediments, may therefore be considered as one among multiple fluid sources. Moreover, the carbon isotopic signature of carbonates $(\sim 0 \%$ vs. PDB) indicates that the source of $\mathrm{C}$ was likely marine metasediments (Piccoli et al., 2016), thus further supporting this interpretation. Considering that locally Stage\# 1 develops within carbonatebearing Mesozoic metasediments, it is plausible that part of the dissolved carbonate during Stage\#1 is then transported for short distances and re- 
(a)

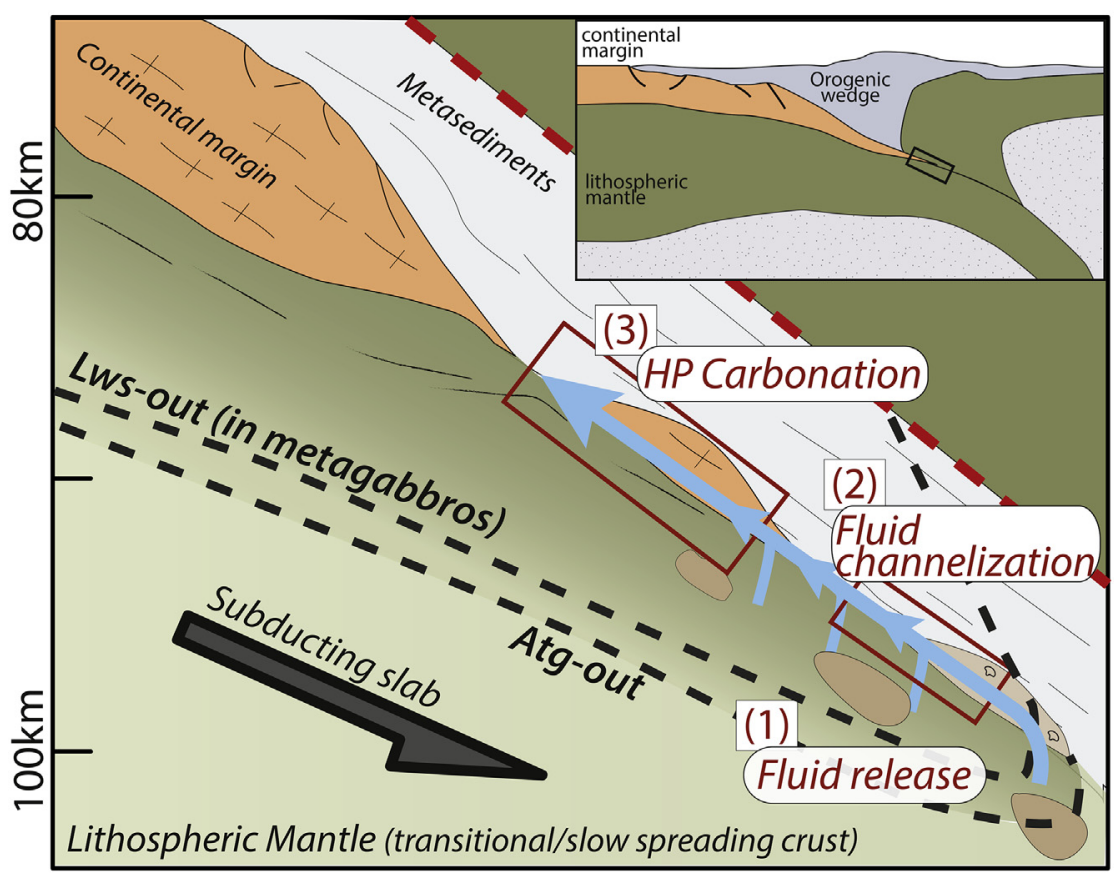

(b)

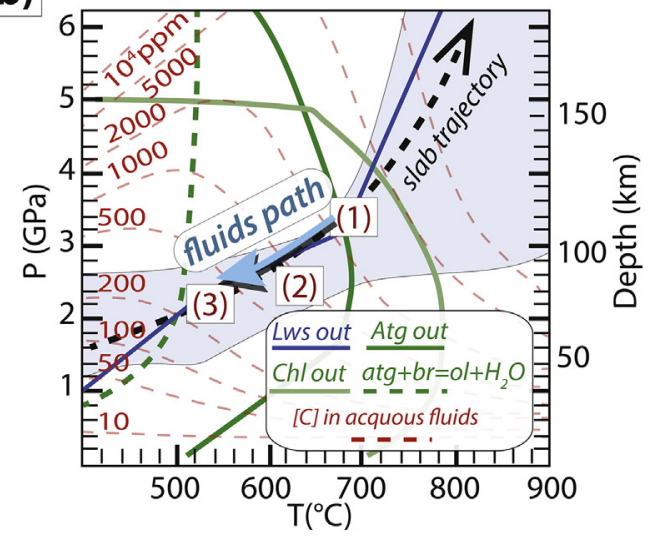

Mesozoic metasediments

Continental-basement rocks

Metabasalt

Metagabbro

Hydrated/dehydrated lithospheric mantle

- - Plate interface

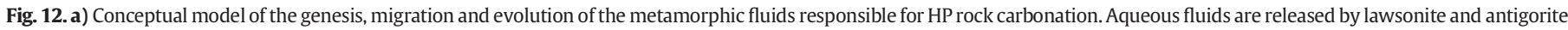

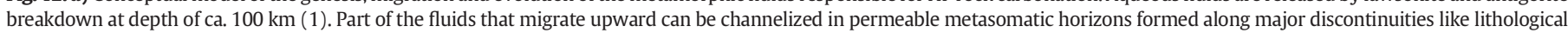

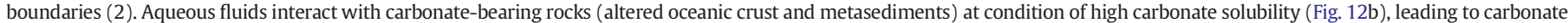

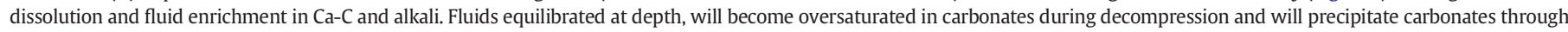

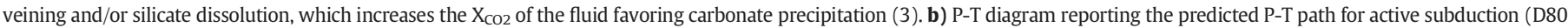

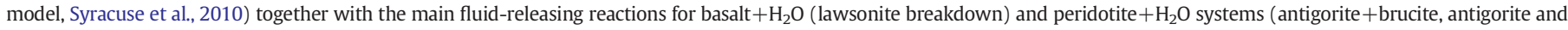

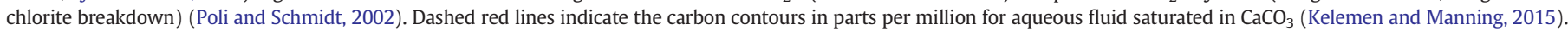

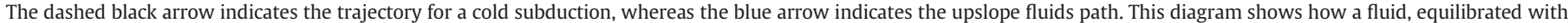

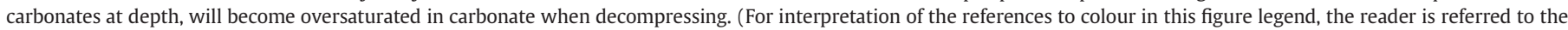
web version of this article.)

precipitated. Nevertheless, this hypothesis cannot explain the observed carbonation of precursor rocks that were originally carbonate-free.

Enrichment in Ca and $\mathrm{C}$ is in most cases accompanied by the formation of Na-rich clinopyroxene ( $\mathrm{Cpx} 2)$, such as omphacite (Na-Al) or aegirine-augite $\left(\mathrm{Na}-\mathrm{Fe}^{3+}\right)$ depending on the nature and oxidation state of the precursor rock. Considering the very low Na content in Stage\# 1 metasomatic rocks because of Na mass loss after Stage\#1 metasomatism ( $-80 \%$, Vitale Brovarone et al., 2014b), we suggest that $\mathrm{Na}$ mass gain occurred during carbonate metasomatism and fluid infiltration, as also indicated by omphacite formation in Stage\#2 carbonate veins (Fig. 3b3). This evidence provides a robust constraint on the circulation of Na-C-Ca-bearing fluids. Sodium mass gain during HP metasomatism is widely reported in different geological settings (Beinlich et al., 2010; Spandler and Hermann, 2006; Galvez et al., 2013; Ague and Nicolescu, 2014; Taetz et al., 2016) and water-rich alkalis- and carbon-bearing fluids are documented by fluid inclusion studies in eclogite-facies oceanic suites (Monviso and Tauren Window; Philippot and Selverstone, 1991; Selverstone et al., 1992).

As is the case for $\mathrm{Ca}$ and $\mathrm{C}$, Na can derive from devolatilization reactions in metasediments. However, if $\mathrm{Na}$ were derived from the metasediments, $\mathrm{K}, \mathrm{Rb}$ and Ba enrichment would also be expected. Moreover, a purely metasediment-derived fluid would be inconsistent with the oxygen isotopic signature of metasomatic carbonate $(\sim 10 \%$ 。SMOW; Piccoli et al., 2016) and with Cr-rich minerals (clinopyroxene, lawsonite and garnet; this study), characteristics that point to mafic/ultramafic sources like metagabbros and/or serpentinite. Alternatively, altered metamafic rocks like metabasalts are possible source of $\mathrm{Na}, \mathrm{Ca}, \mathrm{C}$, and $\mathrm{Cr}$ together with isotopically light oxygen.
Experimental studies consider $\mathrm{Cr}$ as fluid immobile (Kogiso et al., 1997; Green and Adam, 2003). Cr enrichment might be explained by local mobility by diffusion (Rubatto and Hermann, 2003) or residual enrichment. Nevertheless, Cr oscillatory zoning in Stage\#2 minerals such as garnet, and the very low content of $\mathrm{Cr}$ in Stage\#1 rocks, rule out the hypothesis of local $\mathrm{Cr}$ diffusion. Moreover, the formation of $\mathrm{Cr}$ - rich lawsonite in carbonate veins (samples cor13-29c, 1 cor14-RM), clearly document the presence of this element in the circulating fluids at HP conditions.

High $\mathrm{Cr}$ contents and oscillatory zoning in eclogite-facies fluidmediated rocks such as veins have been reported in several settings including the Stage\#1 metasomatic rocks studied in the San Petrone unit. These features are generally interpreted as tracers of mafic/ultramaficderived fluids equilibrated with metagabbro and/or serpentinite (e.g. Tsujimori et al., 2006; Spandler et al., 2011; Tsujimori and Ernst, 2014; Angiboust et al., 2014; Vitale Brovarone et al., 2014b). Lawsonite breakdown in metagabbros may be a possible source for low $\delta^{18} \mathrm{O}, \mathrm{Cr}$ bearing aqueous fluids. Nevertheless, metagabbros are not observed in the San Petrone unit; thus, we consider it unlikely that this lithology was a local fluid source. Another possible source of low $\delta^{18} \mathrm{O}$ aqueous fluids is the breakdown of antigorite serpentinite, which is expected to happen though successive stages from 400 to $700{ }^{\circ} \mathrm{C}$ and 1 to $3 \mathrm{GPa}$ (e.g., Ulmer and Trommsdorff, 1995; Rüpke et al., 2004). Serpentinitederived fluids can account for the observed $\mathrm{Na}$ and $\mathrm{Cr}$ enrichment. For example, Scambelluri et al. (1997) reported high salinity fluid inclusions in eclogitized hydrous peridotite (Erro-Tobbio peridotite, Western Alps). The key point to emphasize is that an external and deeper source of water-rich fluids (metabasalts, metagabbros and/or serpentinite) must 
have been present to account for the mafic/ultramafic geochemical fingerprint of the carbonated metasomatic rocks.

\subsection{Fluid evolution migration pathways}

The aqueous nature of the infiltrating fluid, together with the dominant low $\delta^{18} \mathrm{O}$ isotopic signature of carbonate in Stage\#2 metasomatic rocks points to ultramafic/mafic rocks (serpentinite and metabasites) as the main source of water. However, major dehydration reactions in hydrated mafic/ultramafic systems are not predicted at the P-T conditions of the San Petrone unit $\left(500^{\circ} \mathrm{C}\right.$ and $\left.2 \mathrm{GPa}\right)$, with the exception of partial antigorite breakdown in the presence of brucite (Trommsdorff and Evans, 1980; Scambelluri et al., 1995). More significant dehydration reactions in these systems are expected to take place at higher P-T metamorphic conditions, in the range of $700{ }^{\circ} \mathrm{C}$ and $3 \mathrm{GPa}$, including lawsonite breakdown in metabasite and the antigorite-out reaction in serpentinite (Fig. 12a,b). That is to say, fluid release reactions would happen in a zone between $\sim 10-30 \mathrm{~km}$ deeper than the estimated conditions for metasomatism and carbonation in the study area (Fig. 12a,b). Fluids produced in the deeper part of the slab can then migrate upslope along major discontinuities/permeable layer (Faccenda, 2014; Wilson et al., 2014), and cause metasomatism at lower P conditions (e.g., Bebout and Barton, 1993; Herms et al., 2012; Angiboust et al., 2014). In Section 7.1.3, we concluded that, in our case study, the serpentinite was less permeable than the overlying metasedimentary or gneissic rocks, and this permeability contrast favored fluid channelization along the contact between the serpentinite basement and the overlying metasediments. This conclusion is supported by several studies demonstrating that fluids are channelized by permeable layers or structural features like fold axes, leading to high metamorphic fluid fluxes (i.e. Rye et al., 1976; Yardley and Lloyd, 1995; Skelton et al., 1995; Ague, 2014). Moreover, the fluid-rock interaction during Stage\#1 may have enhanced the permeability of the metasomatic zone (Yardley and Balashov, 1998) with respect to the overlaying metasediments, thus further favoring the channelization of fluids along this permeable layer. This happened along a major interface of the subducting slab, thus allowing slabparallel fluid flow along several kilometers (at least 10-12 in the study area, and probably more). Extremely channelized fluid flow at regional scale is also consistent with the lack of pervasive isotopic homogenization at the scale of the Corsican metaophiolite (Miller et al., 2001).

Compared to analogous models in mélange-type plate interfaces (Bebout and Barton, 1989, 1993; Bebout and Penniston-Dorland, 2016), our study points to two important conclusions. Firstly, the structural localization of metasomatism along the basal unconformity of the subducted metasedimentary pile suggests an important role exerted by major inherited lithospheric lithological discontinuities for the channelization and upward migration of deep fluids. This does not contradict the possible equivalent role played by the plate interface, but suggests that fluid can be channelized at different levels within the subducting slab. Secondly, the results of the study of carbonated metasomatic rocks demonstrate that the composition of the fluid responsible for metasomatism derived by multiple sources from mafic/ultramafic rocks as well as metasediments. The evidence for the multi-source nature of HP fluid allows us to construct an updated model for the evolution of deep fluids by reactive fluid flow.

The model is illustrated in Fig. 12a, which summarizes the main stages of fluid release and fluid-rock interactions bearing on the origin of HP carbonation in the units of Alpine Corsica. Lawsonite and antigorite breakdown releases large amounts of aqueous fluids with light $\delta^{18} \mathrm{O}$ signatures ("1" in Fig. 12a) and characteristic mantle tracers such as $\mathrm{Cr}$. Some fraction of these fluids can be channelized along the basal unconformity of the metasedimentary pile ("2" in Fig. 12a). Channelized fluid flow, parallel to the slab and along a down-T, down-P geothermal gradient as well as along lithological contrasts gives the necessary chemical potential for reactive fluid flow (Fig. 12b). When water-rich fluids initially infiltrate altered oceanic crust and/or metasediments, they can dissolve carbonates, becoming enriched in $\mathrm{Ca}, \mathrm{C}$, as well as leak other elements like $\mathrm{Na}$ ("2" in Fig. 12a, and b).

Successively, carbon-bearing fluids infiltrate silicate-rich rocks and drive carbonation reactions. During HP carbonation, carbonates are precipitated in veins and silicates are dissolved and replaced by carbonates (" 3 " in Fig. 12a). Together with the clear evidence for the infiltration of carbon-bearing fluids, the dissolution of silicates during this phase of fluid-rock interaction might have enhanced a positive feedback for carbonation. As recently proposed by Tumiati et al. (2017), silicate dissolution at HP conditions may be accompanied by the formation of organic complexes in the fluid, which promotes a decrease of water activity and an associated increase of $\mathrm{X}_{\mathrm{CO} 2}$. This increase of $\mathrm{X}_{\mathrm{CO} 2}$ can further favor the stability of carbonate mineral and potentially, enhance carbonation reactions.

The above model is built on observations from an Alpine-type slab characterized by slow-spreading and transitional lithosphere. Its applicability to the global range of subducting slabs will require additional work and the consideration of the specific nature of individual subducting plates, thermal regime, and the associated metasedimentary suites. Nevertheless, our findings, together with reported carbonation processes in greenschist (Nishiyama, 1990; Skelton et al., 1997), blueschist (Kleine et al., 2014) and eclogite facies terrains (Piccoli et al., 2016; Scambelluri et al., 2016; this study), demonstrate that rock carbonation may have a larger impact on the carbon budget in subduction zones than previously estimated, particularly given its apparent efficiency over a wide range of P-T conditions. Furthermore, the reactivity of metafelsic lithologies such as orthogneiss to carbon-bearing fluids opens new perspectives for the evaluation of carbonation processes happening during continental subduction in collisional settings.

\section{Conclusions}

This work provides a structural, microstructural and geochemical overview of carbonate metasomatism in lawsonite-eclogite facies rocks from Alpine Corsica. Reactive fluid flow along major lithospheric lithological interfaces is evidenced by pervasive metasomatism and carbonation accompanied by multiple veining events. Our tectonostratigraphic and petrological study of carbonated metasomatic rocks facilitates inferences regarding the nature of the protolith rock, and provides tools to identify HP carbonation processes in other metamorphic terranes. Carbonate metasomatism is characterized by field evidence for fluid overpressure, including hydraulic breccias and crack-seal veining, and by reaction rinds between disparate lithologies. In most of the cases, the resulting structural and microstructural relationships give corrosion-like textures, notably with heterogeneous consumption and segmentation of silicaterich domains. Fluid-rock interactions are recorded by microstructures (e.g. atoll-like minerals or embayed crystal rims), mineral zoning, and isotopic changes. Geochemical and isotopic data make us propose that the final fluid composition results from successive equilibration during reactive fluid flow. We propose that deeper fluids produced by major dehydration reactions can percolate parallel to the slab and chemically evolve by reactive flow (Fig. 12a). Importantly, we demonstrate that a large set of rock composition is reactive with $\mathrm{COH}$ fluids, ranging from ultramafic to metafelsic.

Supplementary data to this article can be found online at https://doi. org/10.1016/j.lithos.2018.01.026.

\section{Acknowledgements}

The research leading to these results has received funding from the Deep Carbon Observatory, the University Pierre et Marie Curie (Paris 6, Sorbonne Universités) and INSU grant A02017-999403. We thank the DCO Corsica Field Studies grant as well as the DCO Reservoirs and Fluxes and Deep Energy communities. Imène Esteve is thanked for her technical support in the SEM platform. Scanning Electron Microscope 
(SEM) facility of the Institut de Minéralogie, Physique des Materiaux et Cosmochimie is supported by Région Ile de France grant SESAME 2006 N_ I-07-593/R, INSU-CNRS, INP-CNRS, University Pierre et Marie Curie - Paris 6, and by the French National Research Agency (ANR) grant no. ANR-07-BLAN-0124-01. Michel Fialin and Nicolas Rividi (CAMPARIS service) are thanked for their technical support during electron microprobe measurement.

\section{References}

Ague, J.J., 2007. Models of permeability contrasts in subduction zone mélange: Implications for gradients in fluid fluxes, Syros and Tinos Islands, Greece. Chemical Geology 239:217-227. https://doi.org/10.1016/j.chemgeo.2006.08.012.

Ague, J.J., 2014. Fluid Flow in the Deep Crust. In: Holland, Heinrich D., Turekian, K.K. (Eds.), Treatise on Geochemistry, Second edition Elsevier, Oxford:pp. 203-247 https://doi.org/10.1016/B978-0-08-095975-7.00306-5.

Ague, J.J., Nicolescu, S., 2014. Carbon dioxide released from subduction zones by fluidmediated reactions. Nature Geoscience 7, 355-360.

Alt, J.C., Teagle, D.A.H., 1999. The uptake of carbon during alteration of ocean crust. Geochimica et Cosmochimica Acta 63:1527-1535. https://doi.org/10.1016/S00167037(99)00123-4.

Angiboust, S., Pettke, T., De Hoog, J.C.M., Caron, B., Oncken, O., 2014. Channelized Fluid Flow and Eclogite-facies Metasomatism along the Subduction Shear Zone. Journal of Petrology 55:883-916. https://doi.org/10.1093/petrology/egu010.

Bebout, G.E., Barton, M.D., 1989. Fluid flow and metasomatism in a subduction zone hydrothermal system: Catalina Schist terrane, California. Geology 17, 976-980.

Bebout, G.E., Barton, M.D., 1993. Metasomatism during subduction: products and possible paths in the Catalina Schist, California. Chemical Geology 108:61-92. https://doi.org/ 10.1016/0009-2541(93)90318-D.

Bebout, G.E., Penniston-Dorland, S.C., 2016. Fluid and mass transfer at subduction interfaces-The field metamorphic record. Lithos 240-243:228-258. https://doi.org/ 10.1016/j.lithos.2015.10.007.

Beinlich, A., Klemd, R., John, T., Gao, J., 2010. Trace-element mobilization during Cametasomatism along a major fluid conduit: Eclogitization of blueschist as a consequence of fluid-rock interaction. Geochimica et Cosmochimica Acta 74:1892-1922. https://doi.org/10.1016/j.gca.2009.12.011.

Beltrando, M., Manatschal, G., Mohn, G., Dal Piaz, G.V., Vitale Brovarone, A., Masini, E. 2014. Recognizing remnants of magma-poor rifted margins in high-pressure orogenic belts: The Alpine case study. Earth-Science Reviews 131:88-115. https://doi. org/10.1016/j.earscirev.2014.01.001.

Breeding, C.M., Ague, J.J., Bröcker, M., Bolton, E.W., 2003. Blueschist preservation in a retrograded, high-pressure, low-temperature metamorphic terrane, Tinos, Greece: Implications for fluid flow paths in subduction zones. Geochemistry, Geophysics, Geosystems 4.

Caron, J.M., Delcey, R., 1979. Lithostratigraphie des schistes lustrés corses: diversité des series post-ophiolitiques. Comptes Rendus de l'Académie des Sciences Paris 208 , 1525-1528.

Caron, J.-M., Kienast, J.-R., Triboulet, C., 1981. High-pressure-low-temperature metamorphism and polyphase Alpine deformation at Sant'Andrea di Cotone (eastern Corsica, France). Tectonophysics 78, 419-451.

Compagnoni, R., Rolfo, F., Castelli, D., 2012. Jadeitite from the Monviso meta-ophiolite, western Alps: occurrence and genesis. European Journal of Mineralogy 24:333. https://doi.org/10.1127/0935-1221/2011/0023-2164.

Dasgupta, R., 2013. Ingassing, storage, and outgassing of terrestrial carbon through geologic time. Reviews in Mineralogy and Geochemistry 75, 183-229.

Dasgupta, R., Hirschmann, M.M., 2010. The deep carbon cycle and melting in Earth's interior. Earth and Planetary Science Letters 298, 1-13.

Evans, K.A., 2012. The redox budget of subduction zones. Earth-Science Reviews 113: 11-32. https://doi.org/10.1016/j.earscirev.2012.03.003.

Faccenda, M., 2014. Water in the slab: A trilogy. Tectonophysics 614:1-30. https://doi. org/10.1016/j.tecto.2013.12.020

Ferrando, S., Groppo, C., Frezzotti, M.L., Castelli, D., Proyer, A., 2017. Dissolving dolomite in a stable UHP mineral assemblage: evidence from Cal-Dol marbles of the Dora-Maira Massif (Italian Western Alps). American Mineralogist 102, 42-60.

Fournier, M., Jolivet, L., Goffé, B., Dubois, R., 1991. Alpine Corsica metamorphic core complex. Tectonics 10, 1173-1186.

Franz, G., Liebscher, A., 2004. Physical and Chemical Properties of the Epidote Minerals -An Introduction. Reviews in Mineralogy and Geochemistry 56:1-82. https://doi.org/ 10.2138/gsrmg.56.1.1.

Frezzotti, M.L., Selverstone, J., Sharp, Z.D., Compagnoni, R., 2011. Carbonate dissolution during subduction revealed by diamond-bearing rocks from the Alps. Nature Geoscience 4:703-706. https://doi.org/10.1038/ngeo1246.

Galvez, M.E., Martinez, I., Beyssac, O., Benzerara, K., Agrinier, P., Assayag, N., 2013. Metasomatism and graphite formation at a lithological interface in Malaspina (Alpine Corsica, France). Contributions to Mineralogy and Petrology 166:1687-1708. https://doi. org/10.1007/s00410-013-0949-3.

Gorman, P.J., Kerrick, D.M., Connolly, J.A.D., 2006. Modeling open system metamorphic decarbonation of subducting slabs. Geochemistry, Geophysics, Geosystems 7 (4). https://doi.org/10.1029/2005GC001125.

Green, T.H., Adam, J., 2003. Experimentally-determined trace element characteristics of aqueous fluid from partially dehydrated mafic oceanic crust at $3.0 \mathrm{GPa}, 650-700^{\circ} \mathrm{C}$.
European Journal of Mineralogy 15:815. https://doi.org/10.1127/0935-1221/2003 0015-0815.

Hammouda, T., 2003. High-pressure melting of carbonated eclogite and experimental constraints on carbon recycling and storage in the mantle. Earth and Planetary Science Letters 214, 357-368.

Hayes, J.M., Waldbauer, J.R., 2006. The carbon cycle and associated redox processes through time. Philosophical Transactions of the Royal Society of London B: Biological Sciences 361, 931-950.

Herms, P., John, T., Bakker, R.J., Schenk, V., 2012. Evidence for channelized external fluid flow and element transfer in subducting slabs (Raspas Complex, Ecuador). Chemical Geology 310-311:79-96. https://doi.org/10.1016/j.chemgeo.2012.03.023.

Jarrard, R.D., 2003. Subduction fluxes of water, carbon dioxide, chlorine, and potassium. Geochemistry, Geophysics, Geosystems 4:8905. https://doi.org/10.1029/ 2002GC000392.

Jolivet, L., Daniel, J.-M., Fournier, M., 1991. Geometry and kinematics of extension in Alpine Corsica. Earth and Planetary Science Letters 104:278-291. https://doi.org/ 10.1016/0012-821X(91)90209-Z.

Kelemen, P.B., Manning, C.E., 2015. Reevaluating carbon fluxes in subduction zones, what goes down, mostly comes up. Proceedings of the National Academy of Sciences https://doi.org/10.1073/pnas.1507889112 (201507889).

Kelemen, P.B., Matter, J., 2008. In situ carbonation of peridotite for $\mathrm{CO} 2$ storage. Proceedings of the National Academy of Sciences 105:17295-17300. https://doi.org/10.1073/ pnas.0805794105.

Kerrick, D., Connolly, J., 1998. Subduction of ophicarbonates and recycling of $\mathrm{CO}_{2}$ and $\mathrm{H}_{2} \mathrm{O}$. Geology 26, 375-378.

Kerrick, D.M., Connolly, J.A.D., 2001. Metamorphic devolatilization of subducted oceanic metabasalts: implications for seismicity, arc magmatism and volatile recycling. Earth and Planetary Science Letters 189:19-29. https://doi.org/10.1016/S0012-821X (01)00347-8.

Kleine, B.I., Skelton, A.D.L., Huet, B., Pitcairn, I.K., 2014. Preservation of Blueschist-facies Minerals along a Shear Zone by Coupled Metasomatism and Fast-flowing CO2-bearing Fluids. Journal of Petrology 55:1905-1939. https://doi.org/10.1093/petrology/egu045.

Kogiso, T., Tatsumi, Y., Nakano, S., 1997. Trace element transport during dehydration processes in the subducted oceanic crust: 1 . Experiments and implications for the origin of ocean island basalts. Earth and Planetary Science Letters 148:193-205. https://doi. org/10.1016/S0012-821X(97)00018-6.

Kohn, M.J., Spear, F., 2000. Retrograde net transfer reaction insurance for pressuretemperature estimates. Geology 28:1127-1130. https://doi.org/10.1130/0091-7613 (2000) $28<1127$ :RNTRIF $>2.0$. CO; 2 .

Kretz, R., 1983. Symbols for rock-forming mineralsl. American Mineralogist 68, 277-279.

Lagabrielle, Y., Cannat, M., 1990. Alpine Jurassic ophiolites resemble the modern central Atlantic basement. Geology 18 (4), 319-322.

Lagabrielle, Y., Lemoine, M., 1997. Alpine, Corsican and Apennine ophiolites: the slowspreading ridge model. Comptes Rendus de l'Académie des Sciences - Series IIA - Earth and Planetary Science 325:909-920. https://doi.org/10.1016/S1251-8050(97)82369-5.

Lagabrielle, Y., Vitale Brovarone, A., Ildefonse, B., 2015. Fossil oceanic core complexes recognized in the blueschist metaophiolites of Western Alps and Corsica. Earth-Science Reviews 141:1-26. https://doi.org/10.1016/j.earscirev.2014.11.004.

Lahondère, D., 1996. Les schistes bleus et les éclogites à lawsonite des unités continentales et océaniques de la Corse alpine: nouvelles données pétrologiques et structurales (Doctoral dissertation).

Lanari, P., Vidal, O., De Andrade, V., Dubacq, B., Lewin, E., Grosch, E.G., Schwartz, S., 2014 XMapTools: A MATLAB@-based program for electron microprobe X-ray image processing and geothermobarometry. Computers \& Geosciences 62:227-240. https:// doi.org/10.1016/j.cageo.2013.08.010.

Leake, B.E., Woolley, A.R., Arps, C.E., Birch, W.D., Gilbert, M.C., Grice, J.D., Hawthorne, F.C. Kato, A., Kisch, H.J., Krivovichev, V.G, 1997. Report of the subcommittee on amphiboles of the international mineralogical association commission on new minerals and mineral names. Mineralogical Magazine 61, 295-321.

Lombardo, B., Rubatto, D., Castelli, D., 2002. Ion microprobe U-Pb dating of zircon from a Monviso metaplagiogranite: implications for the evaluation of the Piedmont-Liguria Tethys in the Western Alps. Ofioliti 27:109-117. https://doi.org/10.4454/ofioliti v27i2.181.

Malvoisin, B., Chopin, C., Brunet, F., Galvez, M.E., 2011. Low-temperature wollastonite formed by carbonate reduction: a marker of serpentinite redox conditions. Journal of Petrology 53:159-176. https://doi.org/10.1093/petrology/egr060.

Manatschal, G., 2004. New models for evolution of magma-poor rifted margins based on a review of data and concepts from West Iberia and the Alps. International Journal of Earth Sciences 93, 432-466.

Martin, L.A.J., Rubatto, D., Vitale Brovarone, A., Hermann, J., 2011. Late Eocene lawsoniteeclogite facies metasomatism of a granulite sliver associated to ophiolites in Alpine Corsica. Lithos 125:620-640. https://doi.org/10.1016/j.lithos.2011.03.015.

Martin, L.A.J., Rubatto, D., Crépisson, C., Hermann, J., Putlitz, B., Vitale-Brovarone, A., 2014 Garnet oxygen analysis by SHRIMP-SI: matrix corrections and application to highpressure metasomatic rocks from Alpine Corsica. Chemical Geology 374-375: 25-36. https://doi.org/10.1016/j.chemgeo.2014.02.010.

Miller, J.A., Cartwright, I., Buick, I.S., Barnicoat, A.C., 2001. An O-isotope profile through the HP-LT Corsican ophiolite, France and its implications for fluid flow during subduction. Chemical Geology 178, 43-69.

Miyashiro, A., Shido, F., 1984. Tschermak substitution in low-and middle-grade pelitic schists. Journal of Petrology 26 (2), 449-487.

Molina, J.F., Poli, S., 2000. Carbonate stability and fluid composition in subducted oceanic crust: an experimental study on H2O-CO2-bearing basalts. Earth and Planetary Science Letters 176:295-310. https://doi.org/10.1016/S0012-821X (00)00021-2. 
Molli, G., Malavieille, J., 2011. Orogenic processes and the Corsica/Apennines geodynamic evolution: insights from Taiwan. International Journal of Earth Science (Geologische Rundschau) 100:1207. https://doi.org/10.1007/s00531-010-0598-y.

Morimoto, N., 1989. Nomenclature of Pyroxenes. Mineralogy and Petrology 39:55-76. https://doi.org/10.1007/BF01226262.

Nishiyama, T., 1990. CO2-metasomatism of a metabasite block in a serpentine melange from the Nishisonogi metamorphic rocks, southwest Japan. Contributions to Mineralogy and Petrology 104, 35-46.

Oliver, N.H.S., 1996. Review and classification of structural controls on fluid flow during regional metamorphism. Journal of Metamorphic Geology 14:477-492. https://doi. org/10.1046/j.1525-1314.1996.00347.x.

Oliver, N.H.S., Bons, P.D., 2001. Mechanisms of fluid flow and fluid-rock interaction in fossil metamorphic hydrothermal systems inferred from vein-wallrock patterns, geometry and microstructure. Geofluids 1 (2):137-162. https://doi.org/10.1046/j.14688123.2001.00013.x.

Passchier, C., Trouw, R., 2005. Microtectonics.

Péquignot, G., Potdevin, J.L., Caron, J.M., Ohnenstetter, M., 1984. Détritisme ophiolitique dans les Schistes lustrés corses et paléogéographie du domaine piémontais. Bulletin de la Societe Geologique de France 7 (26(5)), 913-920.

Philippot, P., Selverstone, J., 1991. Trace-element-rich brines in eclogitic veins: implications for fluid composition and transport during subduction. Contributions to Mineralogy and Petrology 106, 417-430.

Picazo, S., Müntener, O., Manatschal, G., Bauville, A., Karner, G., Johnson, C., 2016. Mapping the nature of mantle domains in Western and Central Europe based on clinopyroxene and spinel chemistry: Evidence for mantle modification during an extensional cycle. ithos 266, 233-263.

Piccoli, F., Vitale Brovarone, A., Beyssac, O., Martinez, I., Ague, J.J., Chaduteau, C., 2016. Carbonation by fluid-rock interactions at high-pressure conditions: Implications for carbon cycling in subduction zones. Earth and Planetary Science Letters 445:146-159. https://doi.org/10.1016/j.epsl.2016.03.045.

Plank, T., 2014. The chemical composition of subducting sediments. Treatise on Geochemistry $4,607-629$.

Plank, T., Langmuir, C.H., 1998. The chemical composition of subducting sediment and its consequences for the crust and mantle. Chemical Geology 145:325-394. https://doi. org/10.1016/S0009-2541(97)00150-2.

Poli, S., 2015. Carbon mobilized at shallow depths in subduction zones by carbonatitic liquids. Nature Geoscience 8, 633-636.

Poli, S., Schmidt, M.W., 2002. Petrology of Subducted Slabs. Annual Review of Earth and Planetary Sciences 30:207-235. https://doi.org/10.1146/annurev.earth.30.091201.140550.

Ramsay, J.G., 1980. The crack-seal mechanism of rock deformation. Nature 284:135-139. https://doi.org/10.1038/284135a0.

Ravna, E.J.K., Andersen, T.B., Jolivet, L., De Capitani, C., 2010. Cold subduction and the formation of lawsonite eclogite - constraints from prograde evolution of eclogitized pillow lava from Corsica. Journal of Metamorphic Geology 28:381-395. https://doi.org/ 10.1111/j.1525-1314.2010.00870.x

Rubatto, D., Hermann, J., 2003. Zircon formation during fluid circulation in eclogites (Monviso, Western Alps): implications for $\mathrm{Zr}$ and $\mathrm{Hf}$ budget in subduction zones. Geochimica et Cosmochimica Acta 67, 2173-2187.

Rüpke, L.H., Morgan, J.P., Hort, M., Connolly, J.A., 2004. Serpentine and the subduction zone water cycle. Earth and Planetary Science Letters 223:17-34. https://doi.org/ 10.1016/j.epsl.2004.04.018.

Rye, R.O., Schuiling, R.D., Rye, D.M., Jansen, J.B.H., 1976. Carbon, hydrogen, and oxygen isotope studies of the regional metamorphic complex at Naxos, Greece. Geochimica et Cosmochimica Acta 40:1031-1049. https://doi.org/10.1016/0016-7037(76)90045-4.

Scambelluri, M., Müntener, O., Hermann, J., Piccardo, G.B., Trommsdorff, V., 1995. Subduction of water into the mantle: history of an Alpine peridotite. Geology 23, 459-462.

Scambelluri, M. Piccardo, G.B., Philippot, P., Robbiano, A, Negretti, L, 1997. High salinity fluid inclusions formed from recycled seawater in deeply subducted alpine serpentinite. Earth and Planetary Science Letters 148:485-499. https://doi.org/ 10.1016/S0012-821X(97)00043-5.

Scambelluri, M., Bebout, G.E., Belmonte, D., Gilio, M., Campomenosi, N., Collins, N., Crispini, L., 2016. Carbonation of subduction-zone serpentinite (high-pressure ophicarbonate; Ligurian Western Alps) and implications for the deep carbon cycling. Earth and Planetary Science Letters 441:155-166. https://doi.org/10.1016/j. epsl.2016.02.034.

Schneider, M.E., Eggler, D.H., 1986. Fluids in equilibrium with peridotite minerals: implications for mantle metasomatism. Geochimica et Cosmochimica Acta 50, 711-724.

Selverstone, J., Franz, G., Thomas, S., Getty, S., 1992. Fluid variability in 2 GPa eclogites as an indicator of fluid behavior during subduction. Contributions to Mineralogy and Petrology 112:341-357. https://doi.org/10.1007/BF00310465.

Skelton, A.D., Graham, C.M., Bickle, MJ. 1995. Lithological and structural controls on regional 3-D fluid flow patterns during greenschist facies metamorphism of the Dalradian of the SW Scottish Highlands. Journal of Petrology 36, 563-586.

Skelton, A.D.L., Bickle, M.J., Graham, C.M., 1997. Fluid-flux and reaction rate from advective-diffusive carbonation of mafic sill margins in the Dalradian, southwest Scottish Highlands. Earth and Planetary Science Letters 146:527-539. https://doi. org/10.1016/S0012-821X(96)00248-8.
Spandler, C., Hermann, J., 2006. High-pressure veins in eclogite from New Caledonia and their significance for fluid migration in subduction zones. Lithos 89:135-153. https:// doi.org/10.1016/j.lithos.2005.12.003.

Spandler, C., Pettke, T., Rubatto, D., 2011. Internal and External Fluid Sources for Eclogite-facies Veins in the Monviso Meta-ophiolite, Western Alps: Implications for Fluid Flow in Subduction Zones. Journal of Petrology 52:1207-1236. https:// doi.org/10.1093/petrology/egr025.

Syracuse, E.M., van Keken, P.E., Abers, G.A. 2010. The global range of subduction zone thermal models. Physics of the Earth and Planetary Interiors 183:73-90. https://doi. org/10.1016/j.pepi.2010.02.004

Taetz, S., John, T., Bröcker, M., Spandler, C., 2016. Fluid-rock interaction and evolution of a high-pressure/low-temperature vein system in eclogite from New Caledonia: insights into intraslab fluid flow processes. Contributions to Mineralogy and Petrology 171:90. https://doi.org/10.1007/s00410-016-1295-z.

Terry, R.D., Chilinger, G.V., 1955. Comparison charts for visual estimation of percent- age composition. Journal of Sedimentary Petrology 25, 229-234.

Trommsdorff, V., Evans, B.W., 1980. Titanian hydroxyl-clinohumite: formation and breakdown in antigorite rocks (Malenco, Italy). Contributions to Mineralogy and Petrology $72,229-242$.

Tsujimori, T., Ernst, W.G., 2014. Lawsonite blueschists and lawsonite eclogites as proxies for palaeo-subduction zone processes: a review. Journal of Metamorphic Geology 32:437-454. https://doi.org/10.1111/jmg.12057.

Tsujimori, T., Sisson, V.B., Liou, J.G., Harlow, G.E., Sorensen, S.S., 2006. Very-low-temperature record of the subduction process: A review of worldwide lawsonite eclogites. Lithos 92: 609-624. https://doi.org/10.1016/j.lithos.2006.03.054.

Tumiati, S., Tiraboschi, C., Sverjensky, D., Pettke, T., Recchia, S., Ulmer, P., Miozzi, F., Poli, S., 2017. Silicate dissolution boosts the $\mathrm{CO} 2$ concentrations in subduction fluids. Nature Communications 8.

Ulmer, P., Trommsdorff, V., 1995. Serpentine stability to mantle depths and subductionrelated magmatism. Science 268:858. https://doi.org/10.1126/science.268.5212.858.

Vernié, P., Kienast, J.R., Mével, C., 1986. The occurrence of deerite in highly oxidizing conditions within the 'Schistes Lustrés'of eastern Corsica. Journal of Metamorphic Geology 4:385-399. https://doi.org/10.1111/j.1525-1314.1986.tb00359.x.

Vitale Brovarone, A., Herwartz, D., 2013. Timing of HP metamorphism in the Schistes Lustrés of Alpine Corsica: New Lu-Hf garnet and lawsonite ages. Lithos 172-173: 175-191. https://doi.org/10.1016/j.lithos.2013.03.009.

Vitale Brovarone, A., Beltrando, M., Malavieille, J., Giuntoli, F., Tondella, E., Groppo, C., Beyssac, O., Compagnoni, R., 2011a. Inherited Ocean-Continent Transition zones in deeply subducted terranes: Insights from Alpine Corsica. Lithos 124:273-290. https://doi.org/10.1016/j.lithos.2011.02.013.

Vitale Brovarone, A., Groppo, C., Hetényi, G., Compagnoni, R., Malavieille, J., 2011b. Coexistence of lawsonite-bearing eclogite and blueschist: phase equilibria modelling of Alpine Corsica metabasalts and petrological evolution of subducting slabs. Journal of Metamorphic Geology 29:583-600. https://doi.org/10.1111/j.1525-1314.2011.00931.x.

Vitale Brovarone, A., Beyssac, O., Malavieille, J., Molli, G., Beltrando, M., Compagnoni, R., 2013. Stacking and metamorphism of continuous segments of subducted lithosphere in a high-pressure wedge: The example of Alpine Corsica (France). Earth-Science Reviews 116:35-56. https://doi.org/10.1016/j.earscirev.2012.10.003.

Vitale Brovarone, A., Picatto, M., Beyssac, O., Lagabrielle, Y., Castelli, D., 2014a. The blueschist-eclogite transition in the Alpine chain: P-T paths and the role of slowspreading extensional structures in the evolution of HP-LT mountain belts. Tectonophysics 615-616:96-121. https://doi.org/10.1016/j.tecto.2014.01.001.

Vitale Brovarone, A., Alard, O., Beyssac, O., Martin, L., Picatto, M., 2014b. Lawsonite metasomatism and trace element recycling in subduction zones. Journal of Metamorphic Geology 32:489-514. https://doi.org/10.1111/jmg.12074.

Vitale Brovarone, A., Martinez, I., Elmaleh, A., Compagnoni, R., Chaduteau, C., Ferraris, C., Esteve, I., 2017. Massive production of abiotic methane during subduction evidenced in metamorphosed ophicarbonates from the Italian Alps. Nature Communications 8.

Wilson, C.R., Spiegelman, M., van Keken, P.E., Hacker, B.R., 2014. Fluid flow in subduction zones: The role of solid rheology and compaction pressure. Earth and Planetary Science Letters 401:261-274. https://doi.org/10.1016/j.epsl.2014.05.052.

Wood, R.M., 1979. The iron-rich blueschist facies minerals: I, Deerite. Mineralogical Magazine 43, 251.

Yang, P., Rivers, T., 2001. Chromium and manganese zoning in pelitic garnet and kyanite: Spiral, overprint, and oscillatory (?) zoning patterns and the role of growth rate. Journal of Metamorphic Geology 19:455-474. https://doi.org/10.1046/j.0263-4929.2001.00323.x.

Yardley, B., Balashov, V.N., 1998. Modeling metamorphic fluid flow with reactioncompaction permeability feedbacks. American Journal of Science 298, 441-470.

Yardley, B.W., Lloyd, G.E., 1995. Why metasomatic fronts are really metasomatic sides. Geology 23, 53-56.

Zack, T., John, T., 2007. An evaluation of reactive fluid flow and trace element mobility in subducting slabs. Chemical Geology 239:199-216. https://doi.org/10.1016/j. chemgeo.2006.10.020

Zhang, L., Chu, X., Zhang, L., Du, J., 2017. Phase equilibria modelling using major and trace element compositions of zoned garnet and clinopyroxene from southwestern Tianshan eclogites, China. Journal of Asian Earth Sciences 145, 408-423. 